\title{
Physiology of Nitrogen and Calcium Nutrition in Blueberry (Vaccinium sp.)
}

\author{
John W. Doyle, Savithri U. Nambeesan and Anish Malladi *
}

check for updates

Citation: Doyle, J.W.; Nambeesan, S.U.; Malladi, A. Physiology of Nitrogen and Calcium Nutrition in Blueberry (Vaccinium sp.). Agronomy 2021, 11, 765. https://doi.org/ 10.3390/agronomy11040765

Academic Editors: Ioannis E. Papadakis and Marco Landi

Received: 25 February 2021

Accepted: 10 April 2021

Published: 14 April 2021

Publisher's Note: MDPI stays neutral with regard to jurisdictional claims in published maps and institutional affiliations.

Copyright: (c) 2021 by the authors. Licensee MDPI, Basel, Switzerland. This article is an open access article distributed under the terms and conditions of the Creative Commons Attribution (CC BY) license (https:// creativecommons.org/licenses/by/ $4.0 /)$.
Department of Horticulture, University of Georgia, Athens, GA 30602, USA; doylejw@uga.edu (J.W.D.); sunamb@uga.edu (S.U.N.)

* Correspondence: malladi@uga.edu

Abstract: Sustaining the fourfold increase in blueberry (Vaccinium sp.) production witnessed during the previous two decades requires better understanding of its mineral nutrient physiology. The primary goals of this review are to evaluate our current understanding of the physiology of nitrogen $(\mathrm{N})$ and calcium $(\mathrm{Ca})$ nutrition in blueberry. Nitrogen concentration in blueberry ranges from $0.4 \%$ to $>2 \%$ across organs. Blueberry uses $\mathrm{N}$ in various forms (organic and inorganic), but it appears to display preference for ammonium $\left(\mathrm{NH}_{4}{ }^{+}\right)$over nitrate $\left(\mathrm{NO}_{3}{ }^{-}\right)$. The roles of $\mathrm{N}$ acquisition, translocation and assimilation in determining $\mathrm{N}$-source preference in blueberry are evaluated. Calcium plays important roles in determining fruit quality owing to its function in maintaining cell wall and membrane integrity. It is unique in its translocation characteristics being transported primarily via the xylem. Fruit $\left[\mathrm{Ca}^{2+}\right]$ typically declines from around $0.2 \%$ during early development to $<0.05 \%$ at ripening. Modes of $\mathrm{Ca}$ acquisition and transport to the fruit, and various approaches to improve fruit $\left[\mathrm{Ca}^{2+}\right]$ are discussed. Areas where further research is warranted to improve our understanding of $\mathrm{N}$ and Ca physiology in blueberry are identified. Such knowledge is essential for sustainable nutrient management, improving productivity, and enhancing fruit quality in blueberry.

Keywords: blueberry (Vaccinium sp.); calcium transport; calcium-related disorders; N-source preference; nitrogen assimilation; nitrogen uptake

\section{Introduction}

Blueberry (Vaccinium sp. L.), a member of the economically important and geographically widely distributed family Ericaceae, has emerged as a major fruit crop. The rapid and extensive increase in its cultivation is related, in-part, to health-promoting, nutraceutical characteristics associated with blueberry consumption. Numerous studies have demonstrated antioxidant, anti-inflammatory and anti-tumorigenic properties (among others) of blueberry fruit and their extracts [1-3]. Continued interest in its potential health benefits and general adaptability of its cultivation to various temperate regions is likely to ensure sustained growth of blueberry production. Currently, world-wide blueberry cultivation stands at over 119,000 ha (2019), more than double that at the beginning of the current century [4]. Global production exceeded 82,000 metric tons in 2019, an increase of almost 4-fold over that in 2000 [4]. The United States of America is currently the leading producer of blueberries, accounting for about a third of global cultivation at more than 308,000 metric tons. Various types of blueberry are cultivated in the United States (US): northern highbush (Vaccinium corymbosum L.); rabbiteye (V. virgatum Aiton); southern highbush (an inter-specific hybrid of V. corymbosum); and lowbush blueberry (V. angustifolium Aiton). The blueberry genome was sequenced, and a draft version of a wild diploid species genome was released in 2015 [5]. This was further augmented by sequencing of a cultivated tetraploid highbush blueberry (V. corymbosum 'Draper') genome [6]. Sustaining current blueberry production trends requires such advances in our understanding of its genetics and physiology, and subsequently their application to cultural practices. 
One area where considerable gaps in knowledge exist is in our understanding of mineral nutrient physiology in blueberry. Blueberry is adapted to acidic soils and has often been classified as a 'calcifuge', a lime-avoiding plant $[7,8]$. Blueberry plants often display optimal growth at lower $\mathrm{pH}$, typically between 4.0 and 5.5 [8-11]. Under such conditions, availability of most nutrients is limited and consequently, it has long been described as a plant with relatively lower nutritional requirements and slower growth habit [7]. Blueberry plants generally display lower elemental composition in comparison to other major fruit crops $[7,8]$. For example, foliar nitrogen $(\mathrm{N})$ concentration in blueberry is often under $2 \%$ during most of the growing season while that of calcium (Ca) does not typically exceed $1 \%[7,8,12]$. However, this is substantially variable across different Vaccinium species and in response to fertilization [13-15]. Multiple aspects of blueberry morphology and physiology influence their ability to acquire and use nutrients. For example, blueberry roots lack root hairs, may display preference for certain forms of nutrients, and develop mycorrhizal associations with specific fungi $[7,8]$. These features can greatly impact their nutrient acquisition and use characteristics. The goal of this review is to evaluate the physiology of the macronutrient, $\mathrm{N}$, and the secondary macronutrient, $\mathrm{Ca}$.

\section{Nitrogen Physiology in Blueberry}

Nitrogen is a macronutrient with a multitude of functions and is often limiting in crop production. Nitrogen physiology in perennial plant systems involves its acquisition, translocation, assimilation (incorporation of $\mathrm{N}$ into organic molecules), storage, and remobilization $[16,17]$. All these processes influence $\mathrm{N}$ homeostasis and its use in blueberry (Figure 1). These processes also regulate steady-state $\mathrm{N}$ concentration in various tissues of the plant (Table 1).

Table 1. Nitrogen (N) concentration in different parts of a blueberry (Vaccinium sp.) plant.

\begin{tabular}{|c|c|c|c|}
\hline Plant Part & $\begin{array}{l}\text { N Concentration } \\
\text { (\% Dry Weight) }\end{array}$ & Notes & Source \\
\hline \multirow[t]{3}{*}{ Leaves } & $1.2-2.1$ & & 8 \\
\hline & $1.85-2.95$ & & $13^{\mathrm{z}}$ \\
\hline & $1.7-2.7$ & between leaf senescence and fruit harvest & $15^{\mathrm{y}}$ \\
\hline \multirow[t]{3}{*}{ Vegetative growth } & 2.1 & typical period of fruit harvest & $14^{\mathrm{x}}$ \\
\hline & $1.1-4.7$ & During growing season & 13 \\
\hline & $1.5-2.5$ & between anthesis and $\sim 80 \mathrm{~d}$ after anthesis & $17^{\mathrm{w}}$ \\
\hline \multirow[t]{3}{*}{ Woody canes } & $0.4-0.75$ & highest before anthesis; lowest during fruit development & 17 \\
\hline & $0.8-1.7$ & highest at dormancy; low at fruit harvest & 14 \\
\hline & $0.76-1.58$ & highest at dormancy; lowest at fruit harvest & 13 \\
\hline \multirow[t]{3}{*}{ Flower } & $2.1-2.2$ & anthesis & 17 \\
\hline & 5 & & 14 \\
\hline & 5.3 & & 13 \\
\hline \multirow[t]{2}{*}{ Fruit } & $1-1.1$ & at harvest & 17 \\
\hline & 1.37 & at harvest & 13,14 \\
\hline \multirow[t]{2}{*}{ Crown } & $1.2-1.75$ & at fruit harvest and at dormancy & 14 \\
\hline & $0.95-1.73$ & highest at dormancy and lowest during mid-fruit development & 13 \\
\hline \multirow[t]{3}{*}{ Root } & $1.1-1.6$ & Increasing towards end of fruit development & 17 \\
\hline & $1.2-1.6$ & At dormancy and at fruit harvest & 14 \\
\hline & $0.95-2.3$ & $\begin{array}{l}\text { Low during early fruit development and highest during dormancy } \\
\text { (following year) }\end{array}$ & 13 \\
\hline
\end{tabular}

${ }^{\mathrm{z}}$ V. corymbosum 'Bluecrop'; data from $50 \mathrm{~kg} \mathrm{ha}^{-1} \mathrm{~N}$ treatment. ${ }^{\mathrm{y}} \mathrm{V}$. corymbosum (interspecific hybrids; 'Emerald' and 'Farthing'); estimated from $168 \mathrm{~kg} \mathrm{ha}^{-1} \mathrm{~N}$ fertigation treatment. ${ }^{\mathrm{x}} \mathrm{V}$. corymbosum 'Bluecrop'; data from $50 \mathrm{~kg} \mathrm{ha}^{-1} \mathrm{~N}$ treatment. ' $V$. virgatum ('Bonita' and 'Climax'). 


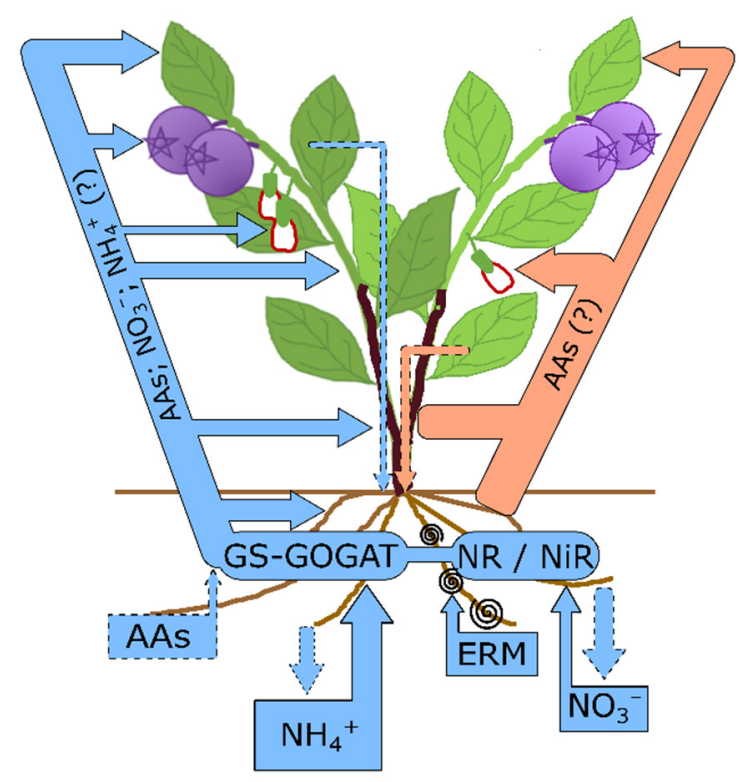

Figure 1. Nitrogen $(\mathrm{N})$ homeostasis in blueberry. The size of arrows or boxes reflects relative size of flow or pool, respectively. Dotted outline indicates a potential mechanism for which evidence is not yet available in blueberry. Nitrogen can be acquired in the inorganic forms as ammonium $\left(\mathrm{NH}_{4}{ }^{+}\right)$or nitrate $\left(\mathrm{NO}_{3}{ }^{-}\right)$, or in the organic form likely as amino acids (AAs). Inorganic $\mathrm{N}$ forms are subject to efflux, particularly at high external concentration. Specific ericoid mycorrhizae (ERM) aid in root $\mathrm{N}$ acquisition. Nitrate may be assimilated within roots by nitrate reductase (NR) and nitrite reductase (NiR). Ammonium acquired from soil or from $\mathrm{NO}_{3}{ }^{-}$assimilation can be incorporated into AAs by glutamine synthase (GS) and glutamine 2-oxoglutarate aminotransferase (GOGAT). Nitrogen can be translocated to leaves, flowers, fruit and shoots in the form of $\mathrm{AAs}, \mathrm{NO}_{3}{ }^{-}$or $\mathrm{NH}_{4}{ }^{+}$. New $\mathrm{N}$ acquired from soil and assimilated or translocated is indicated in blue. Nitrogen recirculation contributes to its homeostasis but has not been investigated in blueberry. Nitrogen supply to new growth occurs largely through remobilization of stored $\mathrm{N}$ from roots and woody shoots. Nitrogen resorption from leaves prior to leaf fall likely contributes to storage $\mathrm{N}$ in woody canes and roots but has not yet been quantified. Nitrogen transport in the plant as remobilization and resorption is shown in orange.

\subsection{Nitrogen Acquisition in Blueberry: Organic $N$}

Plants acquire $\mathrm{N}$ in one of two main forms: organic and inorganic N (Figure 1). Organic $\mathrm{N}$ is derived from soil organic matter and is primarily present in the form of proteins, peptides and free amino acids which can be acquired by plants [18-20]. At least three sub-families of transporter genes, AMINO ACID PERMEASE (AAP), LYSINE/HISTIDINE TRANSPORTER (LHT) and PROLINE TRANSPORTER (ProT) within the larger AMINO ACID/AUXIN PERMEASE (AAAP) family, encode plant proteins directly involved in root uptake of amino acids [21,22]. In arabidopsis (Arabidopsis thaliana (L.) Heynh.), AAP1 and AAP5 facilitate root uptake of neutral and cationic amino acids, respectively [23,24]. LHT1 and LHT6 are expressed in roots and likely facilitate uptake of lysine/histidine, or neutral and acidic amino acids [24-27]. In arabidopsis, ProT1 and ProT2 aid in root uptake of proline and glycine-betaine from the rhizosphere [28,29]. Furthermore, the PEPTIDE TRANSPORTER (PTR) family transporter, PTR1, may be involved in the uptake of short-chain oligopeptides [30,31]. Additionally, proteins may be transported either as peptides/amino-acids following root exudate-mediated proteolysis or directly through endocytosis in arabidopsis and Hakea actites W.R. Barker, a plant adapted to low-fertility soils [32]. Considering their relatively conserved roles across multiple plants it may be speculated that such transporters play substantial roles in organic $\mathrm{N}$ acquisition in blueberry, but evidence for this is limited. In a recent transcriptome analysis of $V$. corymbosum and $V$. arboreum Marshall grown at $\mathrm{pH} 4.5$ and 6.5, six AAPs were identified as substantially upregulated under high $\mathrm{pH}$ in $V$. corymbosum [33]. Additionally, a putative proline trans- 
porter was upregulated in $V$. corymbosum, while a putative LHT1 and an OLIGO-PEPTIDE TRANSPORTER (OPT) family gene were upregulated in V. arboreum under high $\mathrm{pH}(6.5)$ conditions. These data suggest that organic $\mathrm{N}$ transport mechanisms are expressed and functional in acquiring $\mathrm{N}$ at high $\mathrm{pH}$ in blueberry. However, the functional relevance of direct acquisition of amino acids to $\mathrm{N}$ nutrition needs further evaluation in blueberry.

Mycorrhizal associations can facilitate organic $\mathrm{N}$ acquisition in plants [34]. Ericaceae plants form specific mycorrhizal associations termed ericoid mycorrhizal (ERM) associations with certain genera of fungi such as Hymenoscyphus, Pezizella and Oidiodendron [35]. Cranberry (V. macrocarpon Aiton), a close relative of blueberry, formed ERM associations which enhanced their ability to use several $\mathrm{N}$ sources, including organic $\mathrm{N}[18,36,37]$. When ${ }^{15} \mathrm{~N}$ labeled ammonium $\left(\mathrm{NH}_{4}{ }^{+}\right)$sources were supplied to ERM-free and ERM-associated cranberry, shoot dry weight and total $\mathrm{N}$ concentration was enhanced in ERM-associated plants, but concentration of labeled ${ }^{15} \mathrm{~N}$ was lower, suggesting enhanced uptake of unlabeled $\mathrm{N}$-sources, potentially from organic soil $\mathrm{N}$ [36]. In closely related bilberry ( $V$. myrtillus L.) plants with ERM associations, glycine uptake was a major fraction of $\mathrm{N}$ absorbed (up to 91\%) when the labeled amino acid was injected into the organic (mor) layer of the soil in boreal forests [38]. Some ERM may also use organic sources of $\mathrm{N}$ as peptides of smaller chain lengths [39]. Blueberry plants establish similar ERM associations in native soils and under cultivation conditions [35,40-42]. In a survey of commercial blueberry orchards, up to $44 \%$ of total blueberry root length was associated with ERM, although this varied greatly depending on a range of factors such as cultivar, plant age, fruit maturity rate, soil pH and $\mathrm{N}$ fertilization [40]. Hymenoscyphus ericae, one of the ERMs, readily used organic $\mathrm{N}$ as short chain-length peptides and was able to improve $\mathrm{N}$ acquisition and plant dry weight when associated with $V$. corymbosum plants [39]. Recently, rhizosphere microbiomes of greenhouse grown southern highbush, rabbiteye and wild ( . darrowi Camp) blueberry were evaluated [42]. While a common core of the microbiome was apparent across different blueberry types, differences in abundance of fungal microbiomes was also revealed. Rabbiteye blueberry displayed greater abundance of specific ERM and dark septate endophytic taxa. Additionally, specific ERM taxa were associated with each of the blueberry types evaluated, emphasizing that ERM associations are species, and possibly genotype, specific. Whether ERM associations influence nutrient acquisition in agricultural soils, particularly that of $\mathrm{N}$, and overall fitness of blueberry species needs to be resolved. Inoculation of blueberry plants with mycorrhizal peat or a mix of ERM isolates enhanced nutrient uptake (including N), growth and yield suggesting that these plants benefit in terms of $\mathrm{N}$ acquisition through ERM associations under production conditions [35,43]. However, such benefits were determined to be limited in other studies where only a minor increase in growth and no effects on $\mathrm{N}$ acquisition were reported [44].

\subsection{Nitrogen Acquisition in Blueberry: Inorganic $N$}

Plants use inorganic $\mathrm{N}$ as nitrate $\left(\mathrm{NO}_{3}{ }^{-}\right)$or ammonium $\left(\mathrm{NH}_{4}{ }^{+}\right)$. Some plants display preference for an inorganic $\mathrm{N}$ source, which manifests as improved growth and biomass production, higher tissue $\mathrm{N}$ concentration, and/or yield in response to supply of a specific $\mathrm{N}$-source. This parameter is often described as N-source preference $[45,46]$. For example, the conifer white spruce (Picea glauca (Moench) Voss) and the major agronomic crop, rice (Oryza sativa L.) display $\mathrm{N}$-source preference for $\mathrm{NH}_{4}{ }^{+}$. Similarly, some plants within the Ericaceae family, including blueberry, are thought to display N-source preference for $\mathrm{NH}_{4}{ }^{+}$[47]. Across different types of blueberry, multiple studies have suggested that plants display higher growth and/or greater $\mathrm{N}$ accumulation with $\mathrm{NH}_{4}{ }^{+}$as the $\mathrm{N}$-source (Table 2) [48-59]. Plant growth was enhanced, and $\mathrm{N}$ concentration increased when $\mathrm{NH}_{4}{ }^{+}$ was used as the N-source at low $\mathrm{pH}(4.5-4.9)$ in highbush and lowbush blueberry $[9,50,51]$. Similarly, greater growth in new leaves and stems and higher $\mathrm{N}$ concentration with $\mathrm{NH}_{4}{ }^{+}$ as the N-source under low $\mathrm{pH}(3.0-5.0)$ was noted in rabbiteye blueberry [11]. Greater shoot growth and increased chlorophyll and leaf $\mathrm{N}$ concentration in response to $\mathrm{NH}_{4}{ }^{+}$ based fertilization in comparison to $\mathrm{NO}_{3}{ }^{-}$-based fertilization were reported in potted 
southern highbush blueberry [52]. Consistently greater $\mathrm{NH}_{4}{ }^{+}$uptake than that of $\mathrm{NO}_{3}{ }^{-}$ over multiple weeks of cultivation in hydroponic culture was observed in $V$. corymbosum and $V$. arboreum [53]. Furthermore, uptake rates of labeled ${ }^{15} \mathrm{NH}_{4}{ }^{+}$were greater than that of ${ }^{15} \mathrm{NO}_{3}{ }^{-}$during a $24 \mathrm{~h}$ period, resulting in almost 2-fold greater $\mathrm{N}$ accumulation under ${ }^{15} \mathrm{NH}_{4}{ }^{+}$treatment in southern highbush blueberry [54]. However, it should also be noted that several other studies reported little or no $\mathrm{N}$-source preference in blueberry (Table 2) [10,55-57,59].

Table 2. Summary of nitrogen (N)-source preference studies in blueberry (Vaccinium sp.).

\begin{tabular}{|c|c|c|c|c|}
\hline Species & N Concentration (mM) & N-Source Preference & $\begin{array}{c}\text { Suggested } \\
\text { Mechanism/Notes }\end{array}$ & Study \\
\hline V. corymbosum 'Jersey' & $\begin{array}{c}25 \mathrm{mM}(250 \mathrm{~mL} \text { per week); } \\
2-8 \mathrm{mM}^{2} \mathrm{NH}_{4} \mathrm{NO}_{3} \\
\text { or } \mathrm{NH}_{4} \mathrm{Cl}\end{array}$ & $\mathrm{NH}_{4}^{+}$ & $\mathrm{pH}:>6.0 ;<5.2$ & 48 \\
\hline V. corymbosum 'Bluecrop' & $5 \mathrm{mM}$ & None & $\mathrm{pH}: 4.0,6.0$ and 8.0 & 55 \\
\hline V. angustifolium & $1 \mathrm{mM}$ and $10 \mathrm{mM}$ & $\mathrm{NH}_{4}^{+}$ & pH: 4.9 & 50 \\
\hline V. corymbosum 'Berkley' & $1.5 \mathrm{mM}$ & $\mathrm{NH}_{4}^{+}$ & $\begin{array}{c}\mathrm{pH}: 4.5 ; \mathrm{NH}_{4} \mathrm{NO}_{3} \text { displayed } \\
\text { intermediate effects } \\
\text { pH: } 4.5 \text { and } 6.0 ; \mathrm{pH} \text { and }\end{array}$ & 51 \\
\hline V. angustifolium & $2 \mathrm{mM}$ & $\mathrm{NH}_{4}{ }^{+}$at $\mathrm{pH} 4.5$ & $\begin{array}{l}\text { N-source may have } \\
\text { independent effects }\end{array}$ & 9 \\
\hline V. corymbosum 'Wolcott' & $\begin{array}{c}0.44 \mathrm{mM} \text { to } 1.75 \mathrm{mM} \\
\text { (combinations of } \mathrm{NH}_{4}^{+} \\
\text {and } \mathrm{NO}_{3}^{-}\end{array}$ & None & $\begin{array}{c}\text { pH: 5.8-6.2; } \mathrm{pH} \text { of eluent } \\
\text { decreased with } \\
\text { increasing } \mathrm{NH}_{4}^{+} \\
\text {pH: } 4.5 \text { and } 6.5 ; \text { Plants }\end{array}$ & 59 \\
\hline $\begin{array}{c}\text { Interspecific hybrid clone of } \\
V \text {. corymbosum and } V . \\
\text { angustifolium 'Northblue' }\end{array}$ & $2 \mathrm{mM}$ & None & $\begin{array}{l}\text { displayed higher growth at } \\
\text { lower } \mathrm{pH} \text {; plants displayed } \\
\text { similar } \mathrm{N} \text { uptake rates } \\
\text { regardless of } \mathrm{N} \text {-source } \\
\text { bH. } 5.5 \text { continually }\end{array}$ & 10 \\
\hline $\begin{array}{l}V . \text { virgatum 'Tifblue' and } V . \\
\text { corymbosum 'Jersey }\end{array}$ & $\begin{array}{c}1 \mathrm{mM} \text { to } 4 \mathrm{mM} \\
\text { (combinations of } \mathrm{NH}_{4}{ }^{+} \\
\text {and } \mathrm{NO}_{3}{ }^{-} \text {; final } \mathrm{N}: 4 \mathrm{mM} \text { ) }\end{array}$ & None & $\begin{array}{l}\text { corrected; leaves } \\
\text { accumulated greater free } \\
\mathrm{NH}_{4}^{+} \text {with higher } \\
\mathrm{NH}_{4}^{+} \text {supply }\end{array}$ & 57 \\
\hline V. virgatum 'Tifblue' & $1 \mathrm{mM}$ & $\mathrm{NH}_{4}{ }^{+}(\mathrm{pH}: 3.0 ; 4.0)$ & $\mathrm{pH}: 3.0,4.0,5.0$ & 11 \\
\hline V. corymbosum 'Sharpblue' & $\begin{array}{l}\text { Soil drench of } 7.5 \mathrm{mmol} \\
{ }^{15} \mathrm{~N} \text { in } 500 \mathrm{~mL}\end{array}$ & $\mathrm{NH}_{4}^{+}$ & $\begin{array}{c}\mathrm{pH}: 6.5 \text {; Uptake rates higher } \\
\text { for } \mathrm{NH}_{4}^{+} \text {; translocation of } \mathrm{N} \\
\text { to shoots higher for } \mathrm{NH}_{4}{ }^{+}\end{array}$ & 54 \\
\hline V. corymbosum '13-16-A' & $6 \mathrm{mM}$ & $\mathrm{NH}_{4}^{+}$ & $\begin{array}{c}\mathrm{pH}: 3.5-4.2 \text { for } \mathrm{NH}_{4}-\mathrm{N} \text { and } \\
\text { 6.6-7.2 for } \mathrm{NO}_{3}-\mathrm{N}\end{array}$ & 58 \\
\hline $\begin{array}{l}V . \operatorname{arboreum}(V a) \text { and } V \text {. } \\
\text { corymbosum }(V c) \text { 'Misty' }\end{array}$ & $5 \mathrm{mM}$ & $\mathrm{NH}_{4}{ }^{+}$in $V c$ & pH: 5.5 & 53 \\
\hline $\begin{array}{l}V \text {. virgatum 'Alapaha' and } V \text {. } \\
\text { corymbosum 'Sweetcrisp' }\end{array}$ & $5 \mathrm{mM}$ & $\begin{array}{l}\text { None: based on } \mathrm{N} \\
\text { uptake rates }\end{array}$ & pH: 5.0 & 56 \\
\hline $\begin{array}{l}\text { V. corymbosum } \\
\text { 'Emerald' }\end{array}$ & $17.86 \mathrm{mmol} \mathrm{N}$ per week & $\mathrm{NH}_{4}^{+}$ & $\begin{array}{c}\mathrm{NH}_{4} \mathrm{NO}_{3} \text { displayed } \\
\text { marginally better } \\
\text { performance }\end{array}$ & 52 \\
\hline
\end{tabular}

Nitrate is the predominant $\mathrm{N}$-source in soils under high $\mathrm{pH}$, while $\mathrm{NH}_{4}{ }^{+}$is predominant at low $\mathrm{pH}$. In soils, conversion of $\mathrm{NH}_{4}{ }^{+}$to $\mathrm{NO}_{3}{ }^{-}$through nitrification, a two-step process, is mediated by microorganisms. Ammonium in soils is initially oxidized to hydroxylamine and then to $\mathrm{NO}_{2}{ }^{-}$, generally by ammonia-oxidizing bacteria (AOB). Subsequently, $\mathrm{NO}_{2}{ }^{-}$may be oxidized to $\mathrm{NO}_{3}{ }^{-}$via the action of nitrite-oxidizing bacteria (NOB). The AOB species such as Nitrosomonas sp. and Nitrosococcus sp. were considered as major soil microorganisms mediating the initial rate-limiting oxidation step, while Nitrobacter sp. were considered the major organisms facilitating conversion of $\mathrm{NO}_{2}{ }^{-}$to $\mathrm{NO}_{3}{ }^{-}[60,61]$. The growth and activity of nitrifying bacteria are substantially reduced at low $\mathrm{pH}$, and as a result, little nitrification was expected to occur under low $\mathrm{pH}$ conditions such as that of blue- 
berry cultivation [62]. Recently, multiple other organisms, primarily ammonia-oxidizing archaea (AOA), have been demonstrated to facilitate $\mathrm{NH}_{4}{ }^{+}$oxidation to $\mathrm{NO}_{2}{ }^{-}$[63]. In fact, AOA may likely be the numerically predominant organisms capable of ammonia oxidation in most soils [64,65]. Furthermore, the ratio of AOA to AOB is higher at lower $\mathrm{pH}$, and they likely compete for highly limited availability of ammonia [62]. Consequently, it has been proposed that AOA are likely to serve the primary role as nitrifiers in nutrient-poor soils, as well as acid soils supplemented with urea [62]. Together, these studies suggest that nitrification can occur and contribute to $\mathrm{NO}_{3}{ }^{-}$availability in acid soils, such as those used for blueberry production. For example, application of $\left(\mathrm{NH}_{4}\right)_{2} \mathrm{SO}_{4}$ to 'Bluecrop' grown in soils at $\mathrm{pH} 4.8$ resulted in substantial nitrification which was significantly but only temporarily reduced by co-application of a nitrification inhibitor, dicyandiamide (DCD), which inhibits $\mathrm{NH}_{4}{ }^{+}$oxidation to $\mathrm{NO}_{2}{ }^{-}$[66].

Nitrate is generally poorly retained in the soil and is prone to multiple losses including that through denitrification and leaching [67]. It may be hypothesized that inhibition of nitrification in the rhizosphere can limit such losses and allow for enhanced availability of $\mathrm{NH}_{4}{ }^{+}$. Consistently, in other fruit crops such as strawberry (Fragaria $\times$ananassa (Weston) Duchesne ex Rozier (pro sp.), grape (Vitis vinifera L.) and citrus (Citrus sp. L.), application of $\mathrm{NH}_{4}{ }^{+}$-based fertilizers along with nitrification inhibitors enhanced plant growth, fruit yield and fruit quality characteristics [68-70]. Application of DMPP (3,4-dimethylpyrazole phosphate), an inhibitor of ammonia oxidation, along with $\left(\mathrm{NH}_{4}\right)_{2} \mathrm{SO}_{4}$ to potted 'Emerald' southern highbush blueberry plants enhanced leaf $\mathrm{N}$ and chlorophyll content indicating that inhibition of nitrification can increase $\mathrm{NH}_{4}{ }^{+}$acquisition in blueberry [52].

Many plants, including rice, display an ability to specifically release biological nitrification inhibitors (BNIs) that typically inhibit ammonia-oxidation to $\mathrm{NO}_{2}{ }^{-}$, thereby limiting nitrification capacity within the rhizosphere [61,71]. Furthermore, release of BNIs as root exudates often increases in the presence of $\mathrm{NH}_{4}{ }^{+}$[72]. Such reduction of nitrification through specific release of BNIs can enhance $\mathrm{NH}_{4}{ }^{+}$uptake and may serve as an important component of $\mathrm{NH}_{4}{ }^{+}$-preference [71,73]. It would be of high practical value to determine if blueberry displays such capacity for exudation of BNIs in the rhizosphere.

Inorganic $\mathrm{N}$ Acquisition Mechanisms

In many plants, $\mathrm{NO}_{3}{ }^{-}$and $\mathrm{NH}_{4}{ }^{+}$uptake follow bi-phasic patterns dependent on the concentration of the available substrate [74-77]. In the case of $\mathrm{NO}_{3}{ }^{-}$, uptake at low concentrations of available substrate $(<0.5-1 \mathrm{mM})$ is mediated by a high-affinity transport system (HATS) that has constitutive (cHATS) and inducible (iHATS) components [74,75,78-81]. The HATS for $\mathrm{NO}_{3}{ }^{-}$uptake is saturable and follows Michaelis-Menten kinetics. At higher substrate concentrations ( $>1 \mathrm{mM}$ and up to $50 \mathrm{mM}$ ), in addition to the HATS, $\mathrm{NO}_{3}{ }^{-}$uptake is mediated by constitutive or inducible linear uptake mechanisms which operate with lower affinity for $\mathrm{NO}_{3}{ }^{-}$and are referred to as the low affinity transport system (LATS) $[74,75,79-81]$. The above transport systems remain poorly characterized in blueberry. One study described $\mathrm{NO}_{3}{ }^{-}$uptake kinetics in 'Tifblue' rabbiteye blueberry [82]. Here, $\mathrm{NO}_{3}{ }^{-}$depletion from nutrient medium was monitored at $8 \mathrm{~h}$ and $24 \mathrm{~h}$ after provision of various concentrations of $\mathrm{NO}_{3}{ }^{-}$up to $0.2 \mathrm{mM}$. A saturable HATS which followed Michaelis-Menten kinetics with $V_{\max }$ and $K_{m}$ of $1.75 \mu \mathrm{mol} \mathrm{g}^{-1} \mathrm{~h}^{-1}$ and $23 \mu \mathrm{M}$, respectively, was identified [82]. The LATS uptake kinetics of $\mathrm{NO}_{3}{ }^{-}$remain poorly characterized, even though most studies analyzing $\mathrm{NO}_{3}{ }^{-}$uptake in blueberry have used $\mathrm{N}$ concentrations within the LATS range (Table 2 and references therein).

Ammonium uptake also follows a bi-phasic pattern in plants [76,83]. At low available $\mathrm{NH}_{4}{ }^{+}$concentration $(<1 \mathrm{mM})$, a saturable HATS component following Michaelis-Menten kinetics is functional $[83,84]$. At higher concentrations ( $>1 \mathrm{mM}$ and up to around $40 \mathrm{mM}$ ), non-saturable, linear uptake kinetics are evident, in addition to the HATS, as noted previously for $\mathrm{NO}_{3}{ }^{-}$uptake [76]. In rabbiteye blueberry, $\mathrm{NH}_{4}{ }^{+}$uptake within the HATS range displayed saturation kinetics, similar to that noted in other plants. The LATS component of $\mathrm{NH}_{4}{ }^{+}$uptake was not evaluated in this study [85]. 
Nitrogen source preference for the $\mathrm{NH}_{4}{ }^{+}$form may manifest at the level of $\mathrm{N}$ uptake. In white spruce, a plant with known $\mathrm{N}$-source preference for $\mathrm{NH}_{4}{ }^{+}$, its influx was at least 4-fold higher than that for $\mathrm{NO}_{3}{ }^{-}$, potentially owing to atrophied $\mathrm{NO}_{3}{ }^{-}$acquisition mechanisms [86]. Similarly, it may be hypothesized that N-source preference in blueberry occurs, at least in part, at the level of $\mathrm{N}$-uptake. Comparison of $\mathrm{NH}_{4}{ }^{+}$and $\mathrm{NO}_{3}{ }^{-}$uptake kinetic parameters in rabbiteye blueberry suggested that uptake was potentially higher for $\mathrm{NH}_{4}{ }^{+}[82,85]$. Using labeled ${ }^{15} \mathrm{~N}$-sources as drenches, uptake rate for $\mathrm{NH}_{4}{ }^{+}$was noted to be around 2-fold higher than that for $\mathrm{NO}_{3}{ }^{-}$in 'Sharpblue' southern highbush blueberry [54]. However, other studies have indicated little difference between $\mathrm{N}$ sources in $\mathrm{N}$ uptake (Table 2) [56]. Furthermore, it is unclear if such preference exists within both (HATS and LATS) ranges of $\mathrm{N}$ availability.

Four families of transporters are involved in $\mathrm{NO}_{3}{ }^{-}$transport in plants: NITRATE TRANSPORTER 1 (NRT1)/PEPTIDE TRANSPORTER family (NPF); NRT2; CHLORIDE CHANNEL family (CLC) and SLOWLY ACTIVATING ANION CHANNEL family (SLAC) $[87,88]$. Members of the NPF and NRT2 families have demonstrated roles in root uptake of $\mathrm{NO}_{3}{ }^{-}$from the rhizosphere, in addition to facilitating $\mathrm{NO}_{3}{ }^{-}$transport within the plant, while members of the CLC and SLAC families are potentially involved in vacuolar uptake and efflux from guard cells, respectively $[87,89]$. Nitrate uptake at high and low affinities is mediated by secondary active co-transport with $\mathrm{H}^{+} \mathrm{s}$ [79]. High-affinity transport of $\mathrm{NO}_{3}{ }^{-}$is mediated by inducible NRT2 family members. In Arabidopsis, which contains seven members in this family, NRT2.1 facilitates the majority of iHATS in association with NAR2 (NITRATE ASSIMILATION RELATED 2) [88,90]. Low-affinity transport of $\mathrm{NO}_{3}{ }^{-}$is mediated by the larger family (53 members) of NPF, of which many have been characterized, at least partially [88]. Among these, NPF6.3 was the first characterized $\mathrm{NO}_{3}{ }^{-}$ transporter and displays dual-affinity [91]. Depending on the phosphorylation status of a specific threonine residue (T101), a process that is in-turn dependent on external $\mathrm{NO}_{3}{ }^{-}$ concentration, NPF6.3 can switch between high-affinity (phosphorylated) and low-affinity transport (dephosphorylated) [91]. Furthermore, NPF6.3 also functions as a nitrate-sensor and is therefore referred to as a transceptor [92]. Additionally, NPF4.6 is a constitutively expressed low-affinity transporter [93].

Ammonium uptake at low external concentration in plants is facilitated by the AMT family of transporters of which six have been identified in arabidopsis, and four implicated in root acquisition [94-97]. Activity of AMT transporters appears to be additive and de-repressed by low $\mathrm{NH}_{4}{ }^{+}$availability in arabidopsis. Furthermore, these transporters facilitate high-affinity transport of $\mathrm{NH}_{4}{ }^{+}$[97].

In a study of the root transcriptome of $V$. corymbosum roots supplied with $\mathrm{NO}_{3}{ }^{-}$, eight transcripts of members from the NPF family (NPF2.7; NPF2.13; NPF3.1; NPF7.3; NPF8.1) were differentially expressed in response to change in $\mathrm{pH}$ from 4.5 to 6.5 [33]. Three transcripts coding for NPF2.7 were downregulated at $\mathrm{pH}$ 6.5. NPF2.7 encodes a NITRATE EXCRETION TRANSPORTER 1 (NAXT1) that facilitates $\mathrm{NO}_{3}{ }^{-}$efflux from plant roots particularly in response to root zone acidification [98]. These data suggest greater $\mathrm{NO}_{3}{ }^{-}$efflux at lower $\mathrm{pH}$ (4.5) in $V$. corymbosum. Efflux of $\mathrm{N}$ and futile cycling is commonly associated with low affinity nutrient uptake [99]. As external nutrient concentration increases, particularly within the LATS range, the efflux: influx ratio increases, approaching 1 at high external ion concentrations [99]. Considering that the $\mathrm{N}$ concentration used in this study was $0.5 \mathrm{mM}$, it is likely that some futile cycling of $\mathrm{NO}_{3}{ }^{-}$occurred at $\mathrm{pH} 4.5$. NPF7.3 codes for a bi-directional transporter associated with xylem loading and was upregulated at $\mathrm{pH} 6.5$ suggesting increased xylem loading of $\mathrm{NO}_{3}{ }^{-}$[100]. Some of the other NPF genes differentially expressed in this study are likely associated with hormone transport (NPF3.1), peptide transport (NPF8.1), and $\mathrm{NO}_{3}{ }^{-}$remobilization (NPF2.13) [88]. The AMTs were not identified as differentially expressed in this study, likely owing to the use of $\mathrm{NO}_{3}{ }^{-}$as the N-source. Further research is essential to identify and characterize $\mathrm{NO}_{3}{ }^{-}$and $\mathrm{NH}_{4}{ }^{+}$ transporters in blueberry, and to better understand their contributions to $\mathrm{N}$ acquisition and $\mathrm{N}$-source preference. An initial approach in this context can involve characterization of 
the blueberry root transcriptome in response to supply of different $\mathrm{N}$-sources separately within the HATS- and LATS-related concentration ranges.

\subsection{Nitrogen Translocation in Blueberry}

Nitrogen translocation within the plant can occur in the form of $\mathrm{NO}_{3}{ }^{-}, \mathrm{NH}_{4}{ }^{+}$, or organic $\mathrm{N}$ compounds such as amino acids (Figure 1 ). In many plants, $\mathrm{NO}_{3}{ }^{-}$can be either assimilated within the roots following its acquisition or translocated from roots to shoots via the xylem following xylem-loading, and subsequently stored or assimilated in the shoots [101]. Often, $\mathrm{NH}_{4}{ }^{+}$acquired from the soil is assimilated within roots rapidly as its build-up can be toxic to plant cells. The physiological basis of such toxicity is related to the effects of its influx on uptake of other cations, acidification of the rhizosphere, and increased metabolic demands owing to futile cycling, among others [102,103]. Hence, $\mathrm{NH}_{4}{ }^{+}$has often been described as a N-form that is not substantially translocated via the xylem $[104,105]$. Rather, its assimilation products (amino acids, generally glutamine) are transported [101,104,105]. However, this has been disputed as studies with more sensitive analytical methods indicate substantial $\mathrm{NH}_{4}{ }^{+}$transport, reaching $11 \%$ of total translocated $\mathrm{N}$ in the xylem sap of oilseed rape (Brassica napus L.) under $\mathrm{NH}_{4}{ }^{+}$supply [106].

In blueberry, root to shoot transport of different $\mathrm{N}$-forms has only been evaluated indirectly. In 'Sharpblue' southern highbush blueberry, supply of equimolar labeled ${ }^{15} \mathrm{~N}$ sources resulted in greater accumulation of $\mathrm{NH}_{4}{ }^{+}$derived $\mathrm{N}$ than $\mathrm{NO}_{3}{ }^{-}$derived $\mathrm{N}$, even after normalizing for differences in uptake, indicating lower capacity for $\mathrm{NO}_{3}{ }^{-}$translocation [54]. In another study, with V. arboreum and V. corymbosum, increasing $\mathrm{NO}_{3}{ }^{-}$supply from $1 \mathrm{mM}$ to $5 \mathrm{mM}$ did not alter shoot total Kjeldahl $\mathrm{N}$ or $\mathrm{NO}_{3}{ }^{-}$concentration but increased the root $\mathrm{NO}_{3}{ }^{-}$concentration, further indicating low capacity for translocation of this $\mathrm{N}$ form in blueberry [107]. Xylem sap $\mathrm{NO}_{3}{ }^{-}$concentration and $\mathrm{NO}_{3}{ }^{-}$flux in the xylem were not significantly affected by $\mathrm{NO}_{3}{ }^{-}$as the $\mathrm{N}$-source, further supporting lower xylem loading or transport capacity for this form [56]. In other plants such as carob (Ceratonia siliqua L.), limitation in xylem loading of $\mathrm{NO}_{3}{ }^{-}$was associated with reduced capacity of shoot assimilation of $\mathrm{NO}_{3}{ }^{-}$, as its direct supply to the shoots through the stem enhanced assimilation capacity $[108,109]$. Furthermore, in lodgepole pine (Pinus contorta Dougl.) and other conifers, $\mathrm{NO}_{3}{ }^{-}$translocation to the shoots is limited in comparison to that in trembling aspen (Populus tremuloides Michx.), indicating diminished capacity for its loading into the xylem and/or higher capacity for root storage [110,111]. Together, these data suggest that in addition to $\mathrm{N}$ uptake, $\mathrm{N}$ loading into the xylem and its root-to-shoot translocation play important roles in $\mathrm{N}$-source preference in blueberry. As indicated earlier, $V$. corymbosum roots displayed enhanced expression of NPF7.3, a $\mathrm{NO}_{3}{ }^{-}$transporter involved in xylem loading, at higher $\mathrm{pH}$ suggesting lower xylem-loading capacity under acidic $\mathrm{pH}$ conditions $[33,100]$. Further analysis of such transporter expression is essential to determine if limitations in their functions contribute to differential $\mathrm{N}$ loading in blueberry. Ammonium transport in the xylem sap has not been quantified in blueberry owing to the general assumption that it is assimilated prior to translocation. However, higher free $\mathrm{NH}_{4}{ }^{+}$in leaves was reported in response to increasing root supply of $\mathrm{NH}_{4}{ }^{+}$[57]. Considering the potential for $\mathrm{N}$ transport in xylem sap in this form [106], it is worth re-evaluation particularly under different levels of $\mathrm{NH}_{4}{ }^{+}$supply. Additionally, the capacity of, and forms in which amino-acid transport occurs in the xylem, need to be determined in blueberry. Another aspect of $\mathrm{N}$ translocation in plants involves its re-circulation via the phloem (Figure 1). However, such transport in blueberry remains currently un-investigated.

\subsection{Nitrogen Assimilation in Blueberry}

Ammonium is directly assimilated into amino acids, while $\mathrm{NO}_{3}{ }^{-}$is reduced to $\mathrm{NH}_{4}{ }^{+}$ prior to its assimilation. Ammonium is assimilated mainly through the action of glutamine synthetase (GS), which uses glutamate (Glu) and $\mathrm{NH}_{4}{ }^{+}$as substrates to generate glutamine (Gln). Glutamine subsequently reacts with 2-oxoglutarate to generate two molecules of Glu, a reaction catalyzed by glutamine 2-oxoglutarate aminotransferase/glutamate synthase 
(GOGAT) $[16,96,112]$. The GS-GOGAT cycle can often be localized to the plastids in the shoots where it is operational for $\mathrm{NH}_{4}{ }^{+}$derived from $\mathrm{NO}_{3}{ }^{-}$assimilation (following its reduction), or from other metabolic pathways such as photorespiration [16]. Glutamine synthetase can also be localized to the cytosol where it contributes to primary $\mathrm{NH}_{4}{ }^{+}$ assimilation. For example, in rice, loss of OsGS1;2 leads to a reduction of multiple free amino acids and an increase in free $\left[\mathrm{NH}_{4}{ }^{+}\right]$in roots and xylem sap indicating that it is a critical component of primary $\mathrm{NH}_{4}{ }^{+}$assimilation [113]. Considering that $\mathrm{NH}_{4}{ }^{+}$may be the preferred source of $\mathrm{N}$ in blueberry and that $\mathrm{NH}_{4}{ }^{+}$translocated to the shoots likely represents a small proportion, it may be expected that a significant proportion of acquired $\mathrm{NH}_{4}{ }^{+}$is primarily assimilated within roots. However, this has not been extensively tested in blueberry. In V. corymbosum, GS activity was measurable in the shoots, stem and roots in response to different forms of N-supply [58]. However, it was not significantly enhanced by $\mathrm{N}$-supply as $\mathrm{NH}_{4}{ }^{+}$in comparison to that as $\mathrm{NO}_{3}{ }^{-}$, even if greater overall dry weight accumulation occurred under $\mathrm{NH}_{4}{ }^{+}$nutrition [58]. At least three genes potentially coding for GS and one encoding a glutamate synthase were downregulated in V. corymbosum roots at $\mathrm{pH} 6.5$ in comparison to that at 4.5 , suggesting lower root $\mathrm{NH}_{4}{ }^{+}$assimilation under higher $\mathrm{pH}$ [33]. However, two glutamate synthases were also upregulated under these conditions, suggesting that additional characterization is necessary to determine their contribution to root $\mathrm{NH}_{4}{ }^{+}$assimilation in blueberry.

Nitrate reduction to $\mathrm{NH}_{4}{ }^{+}$is a two-step process that is spatially separated in the cell between the cytoplasm and the plastid. Nitrate is initially reduced to nitrite $\left(\mathrm{NO}_{2}{ }^{-}\right)$ in the cytoplasm by nitrate reductase (NR) and requires NADH/NADPH. This reaction is often considered to be rate-limiting for $\mathrm{NO}_{3}{ }^{-}$assimilation. Nitrite is subsequently transported to the plastid where it is rapidly reduced to $\mathrm{NH}_{4}{ }^{+}$by nitrite reductase (NiR). Plants can either reduce $\mathrm{NO}_{3}{ }^{-}$within roots following its acquisition, or in shoots following its translocation $[16,101]$. Shoot $\mathrm{NO}_{3}{ }^{-}$reduction derives input of reductants and ATP from photosynthesis and may be favorable when light is not limiting [114]. Many herbaceous species perform $\mathrm{NO}_{3}{ }^{-}$reduction within shoots following its translocation. In contrast, it was thought that in woody plants much of this occurred in roots [115]. However, following extensive analyses of leaf NR activity in multiple plant taxa, Smirnoff et al. (1984) concluded that woody plant species also display considerable leaf $\mathrm{NO}_{3}{ }^{-}$reduction, particularly when families adapted to low $\mathrm{NO}_{3}{ }^{-}$soils, including Ericaceae members (Erica sp. and Vaccinium sp.), were excluded from the analysis. Ericaceae members evaluated in this study displayed very low or undetectable levels of NR activity in the shoots [116]. Consistently, many studies in blueberry have indicated undetectable levels of NR activity in the shoots (leaves) $[53,58]$. However, several studies have also reported measurable but relatively low leaf NR activity in blueberry $[56,107,117]$. As such, NR activity and $\mathrm{NO}_{3}{ }^{-}$reduction capacity in the shoots (leaves) is lower than that in many other species and may therefore limit the ability of blueberry plants to use $\mathrm{NO}_{3}{ }^{-}$, thereby serving as an additional factor contributing to $\mathrm{N}$-source preference [53,58]. Consequently, much of the $\mathrm{NO}_{3}{ }^{-}$acquired may be assimilated within roots in blueberry [53]. Consistent with this idea, root NR activity is substantially higher than that in shoots $[53,56,58]$. Nitrate assimilation is inducible by the substrate, $\mathrm{NO}_{3}{ }^{-}$, as $\mathrm{NR}$ and $\mathrm{NiR}$ activity are up-regulated in the presence of $\mu \mathrm{M}$ concentrations of $\mathrm{NO}_{3}{ }^{-}$in plants such as barley (Hordeum vulgare) [118-120]. In $V$. corymbosum, root NR activity is detectable with $\mathrm{NO}_{3}{ }^{-}$as the $\mathrm{N}$-source but not with $\mathrm{NH}_{4}{ }^{+}$[58]. Similarly, NR activity and NR transcript abundance in roots are enhanced with $\mathrm{NO}_{3}{ }^{-}$as the $\mathrm{N}$-source [56]. However, increasing root supply of $\mathrm{NO}_{3}{ }^{-}$(beyond $0.5 \mathrm{mM}$ ) does not increase root NR activity [107,121], suggesting that blueberry root NR activity is saturated at these levels of $\mathrm{NO}_{3}{ }^{-}$. Furthermore, continued supply of $\mathrm{NO}_{3}{ }^{-}$over several weeks is often associated with an initial increase followed by decline in root NR activity in $V$. corymbosum and V. virgatum $[53,56,107]$.

It may be likely that limited shoot NR activity observed in blueberry is associated with limited availability of the substrate. Consistently, direct supply of $\mathrm{NO}_{3}{ }^{-}$to shoots through foliar applications of $\mathrm{KNO}_{3}$ transiently increased leaf $\mathrm{NR}$ activity [56]. Additionally, $\mathrm{NO}_{3}{ }^{-}$ 
supply to the cut end of the stem increased $N R$ and $N i R$ transcript abundance by more than 10-fold and 195-fold, respectively, and resulted in an increase in NR activity [56]. These data indicate that blueberry shoot $\mathrm{N}$ assimilation system is responsive to $\mathrm{NO}_{3}{ }^{-}$ availability and that limitations in root uptake and root-to-shoot translocation of $\mathrm{NO}_{3}{ }^{-}$ limit its assimilation capacity in the shoots. However, even with such induction, shoot NR activity was substantially lower than that in many other non-Ericaceous plants and that in herbaceous species $[58,116]$. Together, these data indicate that in addition to limitations in $\mathrm{NO}_{3}{ }^{-}$uptake capacity and translocation, limitations in shoot assimilation capacity also contribute to $\mathrm{N}$-source preference in blueberry.

\subsection{Nitrogen Storage and Remobilization in Blueberry}

In perennial fruit species, $\mathrm{N}$ storage and remobilization play important roles in overall $\mathrm{N}$ nutrition [122-125]. In addition to $\mathrm{N}$ acquired during the current season, $\mathrm{N}$ compartmentalized to storage during previous year(s) contributes to new growth and development, particularly in early spring [124]. In deciduous species, such remobilization of $\mathrm{N}$ reserves determines early spring growth even when $\mathrm{N}$ is available for uptake in the current season $[124,126]$. Nitrogen storage can occur in multiple organs with roots and stems being significant storage organs $[122,124]$. Long-term $\mathrm{N}$ storage can occur in the form of proteins and/or amino acids [123,126]. The relative significance of each pool varies based on species and extent of $\mathrm{N}$ destined for storage [122,127]. For example, $\mathrm{N}$ storage in apple (Malus $\times$ domestica Borkh.) occurs primarily as proteins but can also occur as free amino acids, the proportion of which increases as $\mathrm{N}$ availability increases [127].

Sources of $\mathrm{N}$ contributing to the storage pool are primarily two-fold: $\mathrm{N}$ uptake during the growing season and $\mathrm{N}$ resorption from leaves. In the deciduous $V$. myrtillus L., new $\mathrm{N}$ taken up later in the season (after cessation of vegetative growth) was allocated mainly to roots and woody stems [128]. In the evergreen $V$. vitis-idaea L., new $\mathrm{N}$ taken up during this period was primarily allocated to new leaf growth. These data indicate that in deciduous species $\mathrm{N}$ uptake later in the season is largely allocated to storage, a feature also noted in other perennial fruit crops such as nectarine (Prunus persica (L.) Batsch var. nectarina) [129]. Resorption of nutrients from senescing leaves in deciduous plants contributes to $\mathrm{N}$ storage. Generally, around $20-50 \%$ of leaf $\mathrm{N}$ may be resorbed prior to leaf fall and dormancy [122]. In mature field-grown peach (Prunus persica) trees, $\mathrm{N}$ resorption from leaves in the fall (assuming 50\%) was calculated to represent about $80 \%$ of the storage $\mathrm{N}$ pool and likely sufficient to support $\mathrm{N}$ requirements of early spring growth [130]. In pistachio (Pistacia vera L.), a biennial bearing fruit crop, around $30 \%$ of leaf $\mathrm{N}$ was resorbed, and in the 'On' year contributed to $100 \%$ of $\mathrm{N}$ in the storage $\mathrm{N}$ pool [131]. In blueberry, it is likely that similar resorption may occur and contribute substantially to $\mathrm{N}$ nutrition in the spring particularly in field-grown mature plants of deciduous Vaccinium species (Figure 1). However, this value has not yet been accurately determined for blueberry.

A few studies have attempted to determine the contribution of remobilization to $\mathrm{N}$ nutrition using $\mathrm{N}$ budgets and labeled ${ }^{15} \mathrm{~N}$ in Vaccinium species. Relative contributions of $\mathrm{N}$ from remobilization and current supply were assessed in two cultivars of rabbiteye blueberry ( $V$. virgatum) that differed in synchrony of vegetative and floral bud break in the spring, by labeling the storage $\mathrm{N}$ pool with ${ }^{15} \mathrm{~N}$ supplied as $\mathrm{NO}_{3}{ }^{-}$[17]. In both cultivars, loss of shoot and root dry weights and storage $\mathrm{N}$ was observed before anthesis and during early spring growth indicating that both organs serve as storage units. However, as decline in storage $\mathrm{N}$ and protein concentration was greater in roots, they are likely to serve as the primary storage organs supporting early spring growth. Remobilization contributed around $50-80 \%$ to the $\mathrm{N}$ requirements of early fruit and vegetative growth but contributed lesser at later stages when $\mathrm{N}$ requirements were primarily met through current acquisition of new $\mathrm{N}$ by roots. The contributions of remobilization and current year $\mathrm{N}$ uptake to plant growth in $V$. myrtillus and $V$. vitis-idaea were evaluated by providing ${ }^{15} \mathrm{~N}$ labeled $\mathrm{NH}_{4} \mathrm{NO}_{3}$ during the current year [128]. New leaf and shoot growth, particularly the first flush, was supported by remobilization of $\mathrm{N}(55-80 \%)$. The source organ differed based on the 
species: roots and woody stem in deciduous species, and old leaves and green stems in evergreen species. These studies data clearly demonstrate the significance of remobilization in meeting $\mathrm{N}$ demands during early spring growth in blueberry.

\section{Calcium Physiology in Blueberry}

Foliar $\mathrm{Ca}^{2+}$ concentration, $\left[\mathrm{Ca}^{2+}\right]$, in blueberry is typically lower than that in other fruit crops such as apple [8], although, at below $1 \%$, it is still comparable to that noted in other herbaceous plants [7,14,132]. Consequently, blueberry plants and other calcifuges have been described as having higher efficiency of $\mathrm{Ca}^{2+}$ uptake and/or use $[8,133]$. Calcium availability in soil is generally considered sufficient and its deficiency is not often reported in the field, but plant $\left[\mathrm{Ca}^{2+}\right]$ below $0.2 \%$ may lead to deficiency-related issues in production $[8,134,135]$. Importantly, even with high foliar concentrations, other organs such as fruit may yet display localized $\mathrm{Ca}^{2+}$ deficiency $[8,133,136]$. Such characteristics of $\mathrm{Ca}^{2+}$ homeostasis and relative importance for fruit make understanding of its physiology essential for fruit production in blueberry.

\subsection{Calcium Acquisition in Blueberry}

Calcium is taken up by plants as the divalent cation, $\mathrm{Ca}^{2+}$. Soil factors such as inadequate supply, very low $\mathrm{pH}$, and excess availability of other cations, particularly magnesium $\left(\mathrm{Mg}^{2+}\right), \mathrm{NH}_{4}{ }^{+}$, potassium $\left(\mathrm{K}^{+}\right)$and sodium $\left(\mathrm{Na}^{+}\right)$, affect $\mathrm{Ca}^{2+}$ uptake and induce its deficiency [137-140]. Calcium moves in the soil to roots via mass flow and subsequently enters the apoplastic space within the root from where it can be acquired by root cells and/or be transported to the xylem. The apparent free space (AFS) in the root wherein $\mathrm{Ca}^{2+}$ movement occurs can be divided into the Donnan Free Space (DFS) and the Water Free Space (WFS) [141,142]. In the DFS, negative charges primarily associated with cell wall pectins contribute to the cation exchange capacity (CEC) of the root apoplastic space, and influence movement and distribution of cations such as $\mathrm{Ca}^{2+}[142,143]$. While only a part of the CEC associated with the DFS may be accessible in vivo, it is of substantial and specific importance to $\mathrm{Ca}^{2+}$ movement and distribution, owing to its valence and hydrated size [142,143]. Calcium can be cross linked through ionic interactions with carboxylic groups of pectic material such as homogalacturonans, thereby strongly influencing the free apoplastic $\left[\mathrm{Ca}^{2+}\right]$ and $\mathrm{Ca}^{2+}$ transport (Figure 2) [144]. In the WFS, lack of such interactions allows for less restricted cation movement including that of $\mathrm{Ca}^{2+}$ [142].

In addition to its role as a macronutrient, $\mathrm{Ca}^{2+}$ performs a vital function as a second messenger in plant cells. In this role, it aids in regulating growth and development, relaying external biotic or abiotic stress signals, and eliciting cellular responses $[133,145]$. This role is manifested as an increase in cytosolic $\mathrm{Ca}^{2+}$ concentration, $\left[\mathrm{Ca}^{2+}\right]_{\text {cyt }}$, the amplitude and frequency patterns of which serve as a 'Ca signature' to relay specificity of the message [145]. This function of $\mathrm{Ca}^{2+}$ requires steady state $\left[\mathrm{Ca}^{2+}\right]_{\text {cyt }}$ in un-elicited cells to be in the submicromolar range $\left(\sim 0.1 \mu \mathrm{M}\right.$; Figure 2) $[143,146]$. Additionally, at higher $\left[\mathrm{Ca}^{2+}\right]_{\mathrm{cyt}}, \mathrm{Ca}^{2+}$ can precipitate with phosphates. The required balance between dual functions of $\mathrm{Ca}^{2+}$ greatly influences its uptake and transport within roots.

Calcium uptake by root cells is electrochemically favorable, due in part to low $\left[\mathrm{Ca}^{2+}\right]_{\mathrm{cyt}}$, and is facilitated by $\mathrm{Ca}^{2+}$-permeable channels $[147,148]$. These include CYCLIC NUCLEOTIDE GATED CHANNELS (CNGCs), GLUTAMATE RECEPTOR LIKE PROTEINS (GPRs), ANNEXINS, TWO-PORE CHANNELS (TPCs) and MECHANOSENSITIVE-LIKE $\mathrm{Ca}^{2+}$-permeable channels [147-149]. Following its acquisition by cells, $\mathrm{Ca}^{2+}$ is rapidly compartmentalized into the vacuole, the lumen of the endoplasmic reticulum, into other organelles, or effluxed into the apoplast to ensure that its function as a second messenger is not compromised [150]. This is mediated against the electro-chemical gradient by $\mathrm{Ca}^{2+}$ ATPases (CALCIUM TRANSPORTING ATPases; ACAs) that pump cytosolic $\mathrm{Ca}^{2+}$ into various compartments (or efflux it) and display high-affinity but low-capacity transport, or by $\mathrm{Ca}^{2+} / \mathrm{H}^{+}$-antiporters (exchangers) that facilitate such transport using the proton motive force (PMF) and display low affinity and high-capacity transport [149]. 


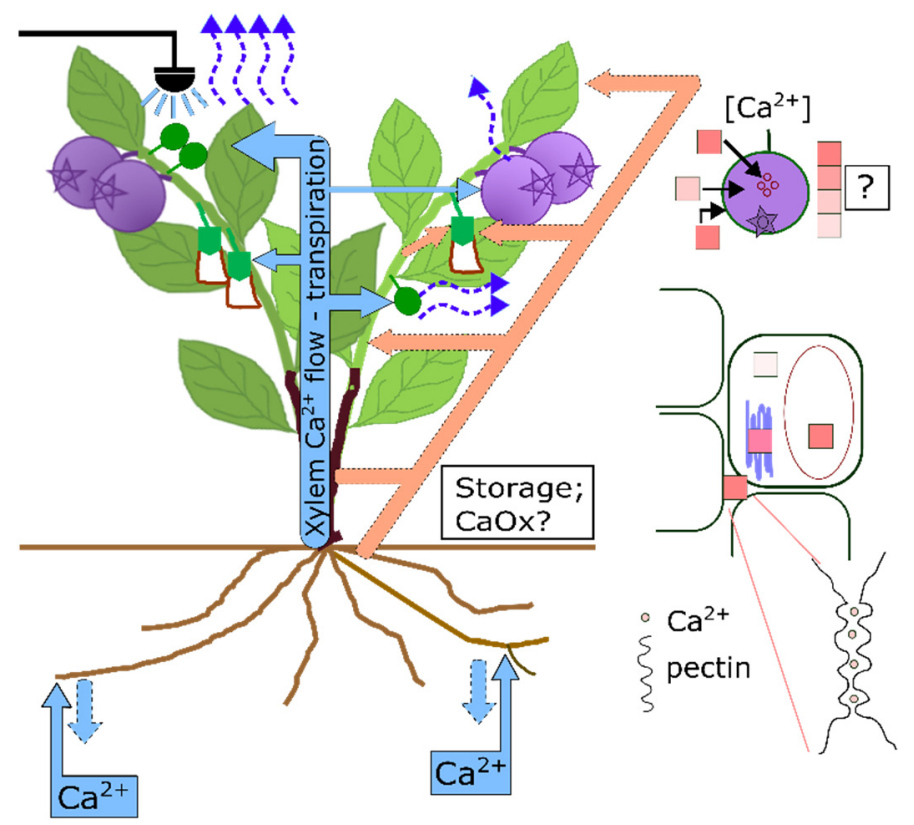

Figure 2. Calcium $\left(\mathrm{Ca}^{2+}\right)$ homeostasis in blueberry. Calcium is acquired primarily along root tips or regions where apoplastic barriers are interrupted (emerging lateral roots). Efflux of $\mathrm{Ca}^{2+}$ may contribute significantly to its homeostasis. Translocation of acquired $\mathrm{Ca}^{2+}$ from roots to shoots occurs in the xylem and may be largely driven by transpiration. Wavy blue arrows above organs indicate transpiration. Organs with higher transpiration rates (indicated with more arrows), such as leaves, may have greater xylem supply of $\mathrm{Ca}^{2+}$ compared to fruit (indicated with fewer arrows). Blue boxes and arrows indicate transport of $\mathrm{Ca}^{2+}$ acquired from roots via the xylem. Remobilization of $\mathrm{Ca}^{2+}$ via phloem is likely minimal. Calcium sources and forms (CaOx: Ca oxalate) involved in supporting new growth such as that of the leaves, flowers and new shoots in the spring are not clear. Here, orange boxes and arrows with dashed outline indicate potential remobilization-related movement of $\mathrm{Ca}^{2+}$ via the xylem. The dashed outline on boxes and arrows indicates putative processes for which evidence is not yet available in blueberry. Foliar applications may serve as an additional source of $\mathrm{Ca}^{2+}$ and may be more effective in increasing fruit $\left[\mathrm{Ca}^{2+}\right]$ when applied during early fruit development. Top right inset demonstrates spatial $\left[\mathrm{Ca}^{2+}\right]$ in the fruit (seeds, pulp and peel). Higher intensity of color in box represents higher relative $\left[\mathrm{Ca}^{2+}\right]$. A putative proximal to distal gradient in $\left[\mathrm{Ca}^{2+}\right]$ is often seen in fruits but remains to be evaluated in blueberry. The bottom right inset depicts $\left[\mathrm{Ca}^{2+}\right]$ in cellular compartments (cytosol, vacuole and endoplasmic reticulum) and the cell wall space. Within the cell wall, $\mathrm{Ca}^{2+}$ mainly binds to pectic polymers and may aid in regulating cell wall properties. Higher intensity of color in the box indicates higher $\left[\mathrm{Ca}^{2+}\right]$.

Radial transport of $\mathrm{Ca}^{2+}$ in roots toward the xylem can potentially follow symplastic or apoplastic routes [146]. A largely symplastic route is likely countered by the critical necessity to maintain sub-micromolar $\left[\mathrm{Ca}^{2+}\right]_{\text {cyt }}$ to support its role as a second messenger. Symplastic transport may still occur in regions where significant barriers for apoplastic transport, such as the Casparian band, exist. In regions of the root where the Casparian band is well developed, $\mathrm{Ca}^{2+}$ may enter endodermal cells, likely through $\mathrm{Ca}^{2+}$-permeable channels $[143,146,148,151]$. Subsequently, $\mathrm{Ca}^{2+}$ may exit into the xylem apoplast through efflux by $\mathrm{Ca}^{2+}$-ATPases and $\mathrm{Ca}^{2+} / \mathrm{H}^{+}$-antiporters $[133,151]$. In regions of roots where the Casparian band is not sufficiently developed, the pathway is largely apoplastic [146]. Consequently, substantial $\mathrm{Ca}^{2+}$ uptake occurs from apical regions of the root where the Casparian band is not yet well developed, or other regions where apoplastic barriers are interrupted (Figure 2) $[133,146]$. When suberin (a key component of the Casparian band) accumulation in roots is enhanced in an arabidopsis mutant, esb1, $\mathrm{Ca}^{2+}$ content in shoots declines, supporting the concept of a largely apoplastic route for $\mathrm{Ca}^{2+}$ flow in roots [152]. 
However, at least in some plants such as onion (Allium cepa), symplastic routes may yet play important roles in radial root $\mathrm{Ca}^{2+}$ transport [153].

A survey of the root transcriptome data indicated differential expression of multiple transcripts coding for $\mathrm{Ca}^{2+}$ transporters in $V$. corymbosum and $V$. arboreum in response to changes in $\mathrm{pH}$ [33]. In $V$. corymbosum, increasing media $\mathrm{pH}$ from 4.5 to 6.5 resulted in a consistent decline in transcript abundance of approximately eight $\mathrm{Ca}^{2+}$-TRANSPORTING ATPases $(A C A s)$. The proteins coded by many of these are potentially localized to the plasma-membrane (based on homology to arabidopsis ACA8, 9 and 10 proteins). Consistently higher expression of multiple putatively PM-localized ACAs at lower $\mathrm{pH}$ (4.5) suggests that under these conditions $V$. corymbosum root cells actively efflux $\mathrm{Ca}^{2+}$. Some of the differentially expressed $A C A s$ code for proteins potentially localized to the ER $(E C A s)$, suggesting increased compartmentation of $\mathrm{Ca}^{2+}$ in root cells at low $\mathrm{pH}$. Potentially, higher influx of $\mathrm{Ca}^{2+}$ into root cells at lower external $\mathrm{pH}$ requires such efflux or compartmentalization to maintain $\left[\mathrm{Ca}^{2+}\right]_{\text {cyt }}$. Furthermore, if these ACAs are localized to the endodermis, these results imply enhanced xylem-loading of $\mathrm{Ca}^{2+}$ under low $\mathrm{pH}$ conditions. Growth of $V$. corymbosum at higher $\mathrm{pH}(6.5)$ was associated with highly reduced abundance of three ALIPHATIC SUBERIN FERULOYL TRANSFERASE (ASFT) transcripts and five CYTOCHROME P450 A86 (CYP86) transcripts associated with suberin biosynthesis $[33,154,155]$. To some extent, this was also noted in V. arboreum (for ASFTs). Together these data suggest greater apoplastic barriers to solute movement in blueberry at low $\mathrm{pH}$ (4.5). Under such conditions, it may be inferred that part of the radial $\mathrm{Ca}^{2+}$ transport to the xylem is symplastic and involves influx into endodermal cells through $\mathrm{Ca}^{2+}$-permeable channels and exit through $\mathrm{Ca}^{2+}$-ATPases or $\mathrm{Ca}^{2+} / \mathrm{H}^{+}$antiporters. The relatively higher expression of several $A C A s$ indicated above supports such a mechanism at low $\mathrm{pH}$. It must be emphasized that these interpretations are preliminary considering that they are-based solely on transcript abundance. Further analysis of physiological and molecular mechanisms of $\mathrm{Ca}^{2+}$ transport and root uptake are clearly essential to better understand $\mathrm{Ca}^{2+}$ acquisition by blueberry roots.

\subsection{Calcium Translocation in Blueberry}

Supply of $\mathrm{Ca}^{2+}$ to organs via phloem is minimal at best, indicating that its internal distribution is predominantly xylem dependent $[134,143]$. Once $\mathrm{Ca}^{2+}$ is loaded into the root xylem, it follows an apoplastic route for transport to shoot, leaves and fruit. This flow is often dependent on the transpiration rate, particularly in organs with higher rates of transpiration [133]. Consequently, higher transpiration rates in leaves result in xylem flow and $\mathrm{Ca}^{2+}$ allocation to these organs rather than the fruit (Figure 2) $[136,156,157]$. In lettuce (Lactuca sativa), increasing transpiration rates by blowing air directly at the meristem increased $\mathrm{Ca}^{2+}$ supply to this region and prevented development of deficiency symptoms [158]. Additionally, treatments that affect transpiration, such as vapor pressure deficit (VPD) reduction, increased humidity, ABA treatments, and application of foliar anti-transpirants reduce symptoms of $\mathrm{Ca}^{2+}$ deficiency in organs/regions with limited xylem transport of $\mathrm{Ca}^{2+}[140,157,159-161]$. In addition to transpiration, $\mathrm{Ca}^{2+}$ movement in the xylem is influenced by CEC of xylem cell walls. Calcium movement within the xylem may involve adsorption and desorption from these exchange sites, potentially reducing the extent of free xylem $\left[\mathrm{Ca}^{2+}\right]$, and at least partially uncoupling its transport from bulk flow in the tissue [134,162]. There is increasing evidence of transpiration-independent mechanisms, such as root pressure, in determining $\mathrm{Ca}^{2+}$ transport to shoot organs including the fruit [163-165]. Additionally, interaction between polar auxin transport and $\mathrm{Ca}^{2+}$ transport may influence $\mathrm{Ca}^{2+}$ delivery into organs, independent of transpiration [166].

\subsubsection{Calcium Transport to the Fruit and Its Distribution}

A key structural function of $\mathrm{Ca}^{2+}$ in plants is maintenance of membrane integrity and cell wall strength $[143,144,167]$. Calcium can cross-link cell wall polysaccharides such as pectins and influence cell wall extensibility (Figure 2) [144]. Excess $\mathrm{Ca}^{2+}$ can increase 
rigidity of the cell wall and limit expansion while low $\mathrm{Ca}^{2+}$ can lead to weakened cell walls and membrane breakdown [144,167]. This in turn influences growth, firmness, and susceptibility to plant pathogens. Consequently, multiple fruit disorders are associated with sub-optimal $\left[\mathrm{Ca}^{2+}\right]$ or $\mathrm{Ca}^{2+}$ distribution in fruits $[162,167,168]$. In many fruits, localized $\mathrm{Ca}^{2+}$ deficiency symptoms appear within a few weeks after anthesis, mainly at the distal end of the organ $[167,168]$.

The rate of fruit growth appears to be inversely correlated with $\mathrm{Ca}^{2+}$ content and with incidence of deficiency symptoms [169]. This may occur owing to an increase in supply of photo-assimilates without concomitant increase in xylem transport of $\mathrm{Ca}^{2+}$. Similarly, correlations between fruit size and $\mathrm{Ca}^{2+}$ deficiency symptom development have been observed in other fruits such as apple [169-172]. Phytohormones may also influence growth and $\mathrm{Ca}^{2+}$ deficiency symptom development. Often, higher gibberellin (GA) levels in organs are correlated with higher growth and lower $\left[\mathrm{Ca}^{2+}\right]$, leading to deficiency symptoms [162]. Consistently, GA applications increase deficiency symptoms, while GA biosynthesis inhibitors increase pericarp $\left[\mathrm{Ca}^{2+}\right]$ and decrease symptoms in tomato. Treatments with GA increase expression of $\mathrm{Ca}^{2+}$-ATPases that presumably localize $\mathrm{Ca}^{2+}$ to organelles, thereby reducing the $\left[\mathrm{Ca}^{2+}\right]_{\text {apo }}$ required to stabilize cell walls and membranes. Auxin transport inhibitor treatments also decrease $\mathrm{Ca}^{2+}$ in apple and tomato fruits and increase deficiency symptoms [134,162]. Relationships among rate of fruit growth, phytohormone signaling and fruit $\left[\mathrm{Ca}^{2+}\right]$ have not yet been explored in blueberry.

In most fruits, majority of fruit $\mathrm{Ca}^{2+}$ is translocated into the organ within a few weeks after anthesis $[162,164,173]$. For example, in melons (Cucumis melo L.), $80 \%$ of the fruit $\mathrm{Ca}^{2+}$ accumulates during early fruit development [174]. In V. corymbosum, fruit $\left[\mathrm{Ca}^{2+}\right]$ declines steadily due to a dilution effect during fruit development [175]. Calcium content per fruit increases during early fruit development but fruit $\mathrm{Ca}^{2+}$ intake declines during mid-fruit development and is negligible at later stages in multiple $V$. corymbosum cultivars [176]. Thus, like in many other fruits, bulk of $\mathrm{Ca}^{2+}$ entry into blueberry fruit appears to occur during early development.

In blueberry, fruit stomatal conductance is 3-fold lower during later stages compared to that at earlier stages of fruit development (petal fall). This is associated with a decline in stomatal density and localization primarily to the distal end of the fruit. Furthermore, at later stages of fruit development, stomates are largely covered with cuticular waxes, contributing to temporal decline in stomatal conductance. Higher stomatal density and conductance observed during early fruit development are still approximately 5 -fold and 2 -fold lower, respectively, than in leaves at the same period [176]. These data support a role for low transpiration in reducing $\mathrm{Ca}^{2+}$ intake into fruit during blueberry fruit growth

Distribution of $\mathrm{Ca}^{2+}$ within fruit is a significant factor affecting development of related disorders such as blossom-end-rot in tomato $[167,168]$. Fruit pedicel and tissues internal to fruit such as seeds or placenta influence $\mathrm{Ca}^{2+}$ delivery to other tissues such as the pericarp $[177,178]$. The majority of apoplastic $\mathrm{Ca}^{2+}$ is bound to the cell wall, and a decrease in this fraction can result in excessive cell enlargement leading to deficiency-related disorders [167]. Calcium localized to the apoplast also influences membrane integrity. In transgenic tomato with down-regulated pectin methylesterase activity, a decrease in cell wall-bound, and an increase in free apoplastic $\mathrm{Ca}^{2+}$ fractions were associated with reduced membrane leakage, likely due to increased association of free $\mathrm{Ca}^{2+}$ with the membrane [168]. In blueberry, higher $\left[\mathrm{Ca}^{2+}\right]$ was noted in the peel and seed tissues, while the lowest was observed in the pulp (Figure 2) [176]. Owing to relatively greater dry matter associated with the pulp, the highest $\mathrm{Ca}^{2+}$ content was noted in this tissue. Higher resolution information on $\mathrm{Ca}^{2+}$ distribution in blueberry fruit is currently lacking. Such information, particularly during progression of fruit growth is needed to better understand its roles in fruit development.

Xylem distribution and functionality in the fruit can influence internal distribution of $\mathrm{Ca}^{2+}$ leading to localized deficiencies and related fruit disorders $[167,168]$. Lower density of xylem is observed in distal parts of tomato fruit, particularly the placental tissue, and 
may contribute to development of deficiency symptoms in this region [179]. In many fruits, xylem functionality is highest during early fruit development and progressively decreases during later stages, potentially owing to growth-related damage of xylem vessels, among other factors $[180,181]$. Analyses across eight fruit species indicated that decrease in xylem conductance and functionality at later stages of fruit development is a conserved phenomenon [178]. Entry of water and most nutrients into fruit at later stages is consequently supported through phloem transport [162,182]. Considering the relative immobility of $\mathrm{Ca}^{2+}$ in the phloem, it is likely that little, if any, $\mathrm{Ca}^{2+}$ is delivered to the fruit through this route. In addition, phytohormones such as auxin, abscisic acid (ABA) and gibberillins (GA) affect vascular development, and thereby uptake and distribution of $\mathrm{Ca}^{2+}$. In tomato fruit GA biosynthesis inhibitor treatments increased the extent of functional xylem [168]. Additionally, application of ABA increased functional xylem vessel number, flow rate of xylem sap, and $\mathrm{Ca}^{2+}$ transport to fruit, thereby reducing deficiency symptom development in tomato [161]. Information on xylem distribution and functionality, and associated changes during development of the blueberry fruit is currently lacking. Such information, along with an understanding of its responses to plant growth regulator applications, is essential to better comprehending $\mathrm{Ca}^{2+}$ transport and accumulation in blueberry.

\subsubsection{Approaches to Improve Fruit $\left[\mathrm{Ca}^{2+}\right]$}

An important potential benefit of higher $\mathrm{Ca}^{2+}$ in fruit is enhanced firmness, especially due to Ca-pectin interactions that may limit pectin depolymerization and hydrolysis, which may in turn contribute to extended postharvest storability (Figure 2). Thus, a focus of $\mathrm{Ca}^{2+}$ nutrition in blueberry has been on applications to improve postharvest fruit quality. Multiple efforts have been made in blueberry to achieve the goal of increasing fruit $\left[\mathrm{Ca}^{2+}\right]$ but have often yielded inconsistent results (Table 3). Effects of soil applications of $\mathrm{CaSO}_{4}$ on fruit quality and biochemical attributes were determined in ' $\mathrm{O}$ 'Neal' and 'Bluecrop' [183]. Applications made in the previous fall were associated with decreased softening and postharvest fruit weight loss, more evidently at $21 \mathrm{~d}$ after cold storage than immediately after harvest. Cell wall associated fruit $\mathrm{Ca}^{2+}$ content increased by $10 \%$ at harvest in both cultivars. While hemicellulose components of the cell wall did not change, tightly bound pectins increased and loosely bound pectins decreased suggesting lower pectin solubilization, thus affecting cell wall disassembly. These data led the authors to conclude that soil $\mathrm{Ca}^{2+}$ applications can increase fruit shelf life by decreasing postharvest water loss and softening. However, in a multi-year study, soil applied lime or gypsum resulted in inconsistent effects on fruit characteristics [184]. Both treatments increased soil $\mathrm{pH}$, and leaf $\left[\mathrm{Ca}^{2+}\right]$ after three years of application, but higher fruit $\left[\mathrm{Ca}^{2+}\right]$ was noted only in one year. The treatments did not consistently affect concentrations of other elements, yield, fruit firmness during postharvest storage, or incidence of common pathogens.

Alternatively, foliar applications of several $\mathrm{Ca}^{2+}$ formulations have been evaluated. In a two-year study $\mathrm{CaCl}_{2}$ was sprayed multiple times between petal fall and harvest in $V$. corymbosum 'Bluecrop' (Table 3) [185]. None of the treatments affected fruit $\left[\mathrm{Ca}^{2+}\right]$, fruit firmness or percentage of sound fruit, including after storage, but increased leaf $\left[\mathrm{Ca}^{2+}\right]$ on a dry weight basis. Multiple formulations of $\mathrm{Ca}^{2+}$ and its combination with Boron (B) were evaluated as foliar applications, beginning from early fruit development (green fruit) in four V. corymbosum cultivars [186]. None of the treatments affected fruit $\left[\mathrm{Ca}^{2+}\right]$, firmness, or postharvest storage (up to $20 \mathrm{~d}$ after harvest). Similarly, pre-harvest foliar applications of $\mathrm{Ca}^{2+}$ either as $\mathrm{Ca}\left(\mathrm{NO}_{3}\right)_{2}$ or chelated-Ca, multiple times during ' $\mathrm{O}$ ' $\mathrm{Neal}$ ' fruit development did not increase fruit $\left[\mathrm{Ca}^{2+}\right]$, or firmness during postharvest storage for up to $28 \mathrm{~d}$ after harvest [187]. Pre-harvest applications ( 30 and $15 \mathrm{~d}$ before harvest) of various $\mathrm{Ca}^{2+}$ formulations had inconsistent effects on fruit firmness and weight in two rabbiteye blueberry cultivars over two years [188]. For example, $\mathrm{CaCO}_{3}$ increased firmness at harvest in 'Powderblue' in one year by $5 \%$ but decreased it in the following year by over $15 \%$. Calcium applications performed prior to fruit set did not affect fruit $\left[\mathrm{Ca}^{2+}\right]$, fruit set or firmness at later stages [189]. Additionally, in related species such as V. macrocarpon, foliar 
$\mathrm{Ca}^{2+}$ applications did not improve fruit $\left[\mathrm{Ca}^{2+}\right]$ or firmness [190]. Increasing application rates alone may not be a solution to increasing tissue $\left[\mathrm{Ca}^{2+}\right]$ with pre-harvest applications, at least with $\mathrm{CaCl}_{2}$, as it results in a linear increase in leaf injury [185]. A potential factor affecting efficacy of foliar $\mathrm{Ca}^{2+}$ applications may be the timing of application in relation to fruit development. Foliar applied $\mathrm{Ca}^{2+}$ is likely to enter fruit tissue through stomates, via the cuticle or through cracks in the cuticle. As indicated earlier, stomatal density and conductance decline sharply with progression of fruit development, while the extent of fruit cuticle increases, thereby limiting penetration of foliar $\mathrm{Ca}^{2+}$ at later stages $[176,191]$. In this context, applications performed during the early stages and using suitable surfactants may improve $\mathrm{Ca}^{2+}$ penetration. Consistently, early (around fruit set) foliar applications of $\mathrm{Ca}^{2+}$ to 'Liberty' blueberry enhanced fruit $\left[\mathrm{Ca}^{2+}\right]$ and increased fruit firmness in comparison to control and late applications [192]. Furthermore, these applications decreased membrane damage as determined by membrane lipid peroxidation, and enhanced antioxidant response through increased superoxide dismutase and radical species scavenging activities. Additionally, inclusion of non-ionic surfactants may contribute to higher $\left[\mathrm{Ca}^{2+}\right]$ in treated fruit [193]. Together, these data suggest that fine-tuning foliar $\mathrm{Ca}^{2+}$ applications by enhancing fruit physiological accessibility can allow for enhanced fruit $\left[\mathrm{Ca}^{2+}\right]$ and quality responses in blueberry. Additional work is needed to evaluate such possibilities.

Table 3. Summary of approaches for altering fruit calcium concentration $\left[\mathrm{Ca}^{2+}\right]$ in blueberry (Vaccinium Sp.).

\begin{tabular}{|c|c|c|c|c|c|}
\hline $\begin{array}{c}\text { Type of } \\
\text { Application }\end{array}$ & Application Details & $\begin{array}{l}\text { Concentration of } \\
\text { Applied Ca }\end{array}$ & $\begin{array}{c}\text { Leaf [Ca] and } \\
\text { Treatment Effect }\end{array}$ & $\begin{array}{l}\text { Fruit [Ca] and } \\
\text { Treatment Effect }\end{array}$ & Source \\
\hline \multirow[t]{2}{*}{ Soil } & $\begin{array}{l}\text { Calcitic lime; } \mathrm{CaSO}_{4} ; \\
\text { V. corymbosum; }\end{array}$ & $\begin{array}{l}1100 \text { and } 550 \mathrm{~kg} \\
\text { ha }^{-1} \text { per year; } \\
\text { four-year } \\
\text { applications }\end{array}$ & $\begin{array}{c}0.2-0.45 \% \\
\text { increased during } \\
\text { later years }\end{array}$ & $\begin{array}{c}0.03-0.07 \% \\
\text { inconsistent increase }\end{array}$ & 184 \\
\hline & $\begin{array}{c}\mathrm{CaSO}_{4} ; \text { previous } \\
\text { season application; } V . \\
\text { corymbosum }\end{array}$ & $600 \mathrm{~kg} \mathrm{ha}^{-1}$ & NA & $\begin{array}{l}\text { Cell wall }\left[\mathrm{Ca}^{2+}\right] \\
\text { increased by }>10 \% \text {; } \\
\text { firmness increased }\end{array}$ & 183 \\
\hline \multirow[t]{6}{*}{ Foliar } & $\begin{array}{c}\mathrm{CaCl}_{2} ; \text { Nutrical; } V . \\
\text { corymbosum }\end{array}$ & $1-24.2 \mathrm{~kg} \mathrm{ha}^{-1}$ & $\begin{array}{c}0.25-0.44 \% \\
\text { increased at higher } \\
\text { rates }\end{array}$ & $0.03-0.04 \% ; \mathrm{NS}$ & 185 \\
\hline & $\begin{array}{c}\mathrm{CaCl}_{2} ; \mathrm{Ca} \text { silicate; } \mathrm{Ca} \\
\text { chelate; Ca acetate; } V . \\
\text { corymbosum }\end{array}$ & $0.34-0.67 \mathrm{~kg} \mathrm{ha}^{-1}$ & $0.6-1.8 \% ; \mathrm{NS}$ & $0.02-0.06 \%$; NS & 186 \\
\hline & $\begin{array}{l}\mathrm{Ca}\left(\mathrm{NO}_{3}\right)_{2} ; \text { chelate } \\
\text { Ca-oxide; } V . \\
\text { corymbosum }\end{array}$ & $\begin{array}{c}0.36-0.78 \mathrm{~kg} \mathrm{ha}^{-1} \\
\text { applied four times } \\
\text { during fruit } \\
\text { development }\end{array}$ & $0.64 \%$ & $\begin{array}{l}0.11 \% \text { (at harvest); NS; } \\
\text { firmness increased } \\
\text { but inconsistent }\end{array}$ & 187 \\
\hline & $\begin{array}{c}\mathrm{Ca}\left(\mathrm{NO}_{3}\right)_{2} ; \\
\text { neutralized } \mathrm{CaCo} ; \\
\text { chelated } \mathrm{Ca} ; V . \\
\text { virgatum }\end{array}$ & $\begin{array}{l}0.65 \mathrm{~kg} \mathrm{ha}{ }^{-1} ; 0.1 \mathrm{~kg} \\
\text { ha }^{-1} ; 0.56 \mathrm{~kg} \mathrm{ha}^{-1} \\
\text { applied twice } \\
750-1500 \text { ppm; } 150\end{array}$ & $\begin{array}{c}\text { Inconsistent change } \\
\text { (18\% increase and } \\
26 \% \text { decrease) }\end{array}$ & $\begin{array}{l}\text { NS; inconsistent } \\
\text { change in firmness }\end{array}$ & 188 \\
\hline & $\underset{\text { corymbosum }}{\mathrm{CaCl}_{2} \text { and } \mathrm{CaSO}_{4} ; V .}$ & $\begin{array}{l}\text { ppm, respectively; } \\
\text { applied six times } \\
\text { during fruit } \\
\text { development }\end{array}$ & $0.6-0.9 \% ; \mathrm{NS}$ & $0.04-0.06 \% ; \mathrm{NS}$ & 189 \\
\hline & $\begin{array}{c}\mathrm{CaCl}_{2} ; \text { Ca phosphite; } \\
\text { Ca thiosulfate } \\
\text { solution; } V . \\
\text { corymbosum }\end{array}$ & $\begin{array}{c}0.63 \mathrm{~kg} \mathrm{ha}^{-1} ; 0.2 \mathrm{~kg} \\
\mathrm{ha}^{-1} ; \text { and } 0.42 \mathrm{~kg} \\
\mathrm{ha}^{-1} ; \text { up to } 2.5 \mathrm{~kg} \\
\mathrm{ha}^{-1} \text { and up to } \\
3 \text { times }\end{array}$ & $0.57-0.75 \%$ & $\begin{array}{c}\text { negative correlation } \\
\text { with fruit drop; } \\
0.11-0.19 \% \text { in early } \\
\text { fruit and } 0.04-0.06 \% \\
\text { in ripe fruit; increased } \\
\text { with high rates }\end{array}$ & 193 \\
\hline Postharvest dip & $\begin{array}{c}\mathrm{CaCl}_{2} \text { immersion; } V . \\
\text { corymbosum }\end{array}$ & $0.4-0.8 \mathrm{~kg} \mathrm{ha}^{-1}$ & $\mathrm{NA}$ & $\begin{array}{c}\text { Increase in firmness } \\
\text { with increasing }\left[\mathrm{Ca}^{2+}\right] \\
\text { Linear increase in } \\
\text { fruit firmness with } \\
\text { increasing }\left[\mathrm{Ca}^{2+}\right] \text { in } \\
\text { dip; objectionable } \\
\text { taste }\end{array}$ & 194 \\
\hline
\end{tabular}


Postharvest applications of $\mathrm{Ca}^{2+}\left(\mathrm{CaCl}_{2}\right)$ have been evaluated to determine their effects on fruit quality (Table 3) [194]. A positive correlation between $\mathrm{Ca}^{2+}$ application rate, and fruit texture and undamaged berries was noted, indicating that a concentration of $2-4 \%$ of $\mathrm{CaCl}_{2}$ results in reduction of physical injury to fruit. However, at these application rates, fruit retained residue on the surface and taste panelists rated the fruit as salty [194]. Potentially, if fruits are washed immediately after treatment, residue and taste effects may be minimized, but this may occur at the expense of treatment efficacy.

Specific disorders associated with $\mathrm{Ca}^{2+}$ deficiency have not yet been clearly defined in blueberry fruit. Green fruit drop (GFD) is potentially one such disorder associated with $\mathrm{Ca}^{2+}$ deficiency. It has been noted in V. corymbosum 'Draper' in British Columbia, Canada, and in Washington, USA, and has been compared to bitter pit as excised fruit show interior browning while external tissues appear normal [193]. Approximately 5-50\% of the crop can be lost to this physiological disorder which manifests immediately prior to ripening-associated change in fruit color. A negative correlation between $\left[\mathrm{Ca}^{2+}\right]$ in ripe fruit and GFD was observed. Furthermore, higher incidence of GFD was associated with enhanced plant vigor owing to greater $\mathrm{N}$ availability. As noted previously, greater shoot vigor may limit $\mathrm{Ca}^{2+}$ availability/flux to low transpiring organs such as the fruit. Foliar $\mathrm{Ca}^{2+}$ applications, particularly as $\mathrm{CaCl}_{2}$ with a surfactant applied several times during early stages of fruit development, were effective in limiting GFD in 'Draper' (Table 3).

\subsection{Calcium Storage and Remobilization in Blueberry}

The function of $\mathrm{Ca}^{2+}$ as a second messenger requires that $\mathrm{Ca}^{2+}$ in the cytoplasm is rapidly compartmentalized into cell organelles from where it can be released back to the cytosol in response to a stimulus $[145,195]$. The role of compartmentalized $\mathrm{Ca}^{2+}$ as a functional reserve may be limited considering that it has limited phloem mobility. In fact, $\mathrm{Ca}^{2+}$ in the vacuole may have very limited remobilization capacity [143]. The majority of $\mathrm{Ca}^{2+}$ in tissues may be present in the bound fraction of the cell wall and the extent to which it functions as a re-mobilizable reserve is not clear. However, a few cases of $\mathrm{Ca}^{2+}$ remobilization have been described. During senescence, $\mathrm{Ca}^{2+}$ from older leaves was remobilized in barley (Hordeum vulgare) and wheat (Triticum aestivum), and substantial remobilization of $\mathrm{Ca}^{2+}$ from root to shoot occurred in Brassica napus subjected to $\mathrm{Ca}^{2+}$ deficiency [196]. Additionally, in response to extreme stress, $\mathrm{Ca}^{2+}$ remobilized from older leaves [197]. It should be noted that in all such cases, remobilization likely occurred primarily via the xylem [198].

Calcium storage and remobilization potentials, and their forms are relatively unknown in blueberry and warrant investigations. As much of early spring growth is supported by reserves from previous year(s), it is important to determine if $\mathrm{Ca}^{2+}$ requirements during this period are met through remobilization via the xylem. This may be particularly important for two reasons: 1 . Maximizing $\mathrm{Ca}^{2+}$ entry during early growth is essential as it is the primary period for its accumulation in the developing fruit [191]; and 2. Lack of sufficient foliage immediately following floral budbreak may limit transpiration, thereby limiting $\mathrm{Ca}^{2+}$ entry into shoot organs through new uptake. In the absence of new uptake, three potential sources may be speculated to support $\mathrm{Ca}^{2+}$ requirements of early growth: buds, woody stems, and roots (Figure 2). If $\mathrm{Ca}^{2+}$ stored in buds is the primary source, a sharp reduction in $\left[\mathrm{Ca}^{2+}\right]$ may be expected during early growth following bud-break, but this has not yet been determined in blueberry. Highly localized remobilization of $\mathrm{Ca}^{2+}$ from woody stems may support early growth. Limited and localized remobilization via the xylem has been suggested previously as a potential mechanism of $\mathrm{Ca}^{2+}$ translocation in plants $[162,198]$. Alternatively, $\mathrm{Ca}^{2+}$ stored in roots may be remobilized to new shoots during early spring growth. Relative contributions of remobilization from the above $\mathrm{Ca}^{2+}$ sources to support early growth prior to new soil $\mathrm{Ca}^{2+}$ uptake clearly warrants further investigation in blueberry. Evidence for such $\mathrm{Ca}^{2+}$ remobilization-based support of early growth has been documented in other fruit species such as apple [162]. 
Calcium accumulation is frequently observed in plants as Ca-oxalate $(\mathrm{CaOx})$ crystals. These crystals generally accumulate within vacuoles of specialized cells called idioblasts, but can also occur in other regions [199]. Accumulation of CaOx may aid in regulation of $\mathrm{Ca}^{2+}$ homeostasis, protection against herbivory, and potentially as a mechanism of elimination of excess $\mathrm{Ca}^{2+}[198,199]$. In many plants, increase in $\mathrm{Ca}^{2+}$ availability results in higher $\mathrm{CaOx}$ levels. Calcium appears to accumulate to a very large extent as $\mathrm{CaOx}$ crystals in leaves and roots of fruit species such as pecan, peach and grape (Vitis sp.) [200-202]. It remains to be determined if and where $\mathrm{Ca}^{2+}$ accumulates as $\mathrm{CaOx}$ in blueberry. Particularly, it would be important to determine if blueberry can accumulate $\mathrm{CaOx}$ under conditions of excess $\mathrm{Ca}^{2+}$ availability (Figure 2). Blueberries appear to produce oxalic acid (Nambeesan and others, unpublished results). The role of $\mathrm{CaOx}$ as a storage form that can be remobilized is debated. Although $\mathrm{Ca}^{2+}$ can become bioavailable from $\mathrm{CaOx}$, particularly when in the druse (crystalline aggregation) crystal form, the extent of remobilization is spatially limited [198,203]. Hence, even if CaOx accumulation occurs in blueberry, further investigations will be necessary to determine if it is a source for $\mathrm{Ca}^{2+}$ remobilization.

\section{Conclusions}

Blueberry plants acquire and use multiple sources of N. However, the significance and capacity for use of certain forms such as organic $\mathrm{N}$ needs further evaluation in typical cultivation conditions. Blueberry also appears to display N-source preference for the inorganic $\mathrm{N}$-form, $\mathrm{NH}_{4}{ }^{+}$. The physiological basis for such preference may be related to its acquisition, translocation and assimilation. Further research is essential to elucidate mechanisms associated with inorganic $\mathrm{N}$-source acquisition, its translocation and assimilation in blueberry. Specifically, identification of $\mathrm{NH}_{4}{ }^{+}$and $\mathrm{NO}_{3}{ }^{-}$transporters and their characterization at low and high $\mathrm{N}$ availability, and in different parts of the root, is required to better understand the physiology of its acquisition and transport. Furthermore, forms of $\mathrm{N}$ translocated in the plant and their assimilation in response to varying $\mathrm{N}$ availability need to be determined at various stages of the annual cycle. An initial approach to address this could involve analyses of changes in the root transcriptome in response to different sources of inorganic $\mathrm{N}$, and at varying $\mathrm{N}$ availability. An additional area that warrants further research regards $\mathrm{N}$ storage and remobilization. Primary organs of storage, forms, and relative proportions of storage $\mathrm{N}$ derived from various pools need to be clearly determined in blueberry.

Calcium uptake by plant roots, its transport to the xylem and subsequently to the economically significant organ, fruit, remain to be elucidated in blueberry. Although Carelated blueberry fruit disorders have not yet been unequivocally identified, it remains likely that $\mathrm{Ca}^{2+}$ plays important roles in regulating fruit quality at harvest and during postharvest storage. Hence, it is important to better understand $\mathrm{Ca}^{2+}$ entry and distribution in the fruit. In this context, it will be important to determine storage sources and forms that supply $\mathrm{Ca}^{2+}$ to the fruit during early development, prior to emergence of significant foliage. Furthermore, roles of fruit transpiration and xylem functionality in determining fruit $\mathrm{Ca}^{2+}$ entry and distribution need to be evaluated. Additionally, identification and characterization of various transporters involved in regulation of fruit $\mathrm{Ca}^{2+}$ uptake can greatly enhance our understanding of its physiology in the fruit.

Information gained through research in the above areas can aid in understanding $\mathrm{N}$ and $\mathrm{Ca}$ nutrition in blueberry. Importantly, decisions regarding $\mathrm{N}$ and Ca nutrient management in blueberry production can be greatly informed by knowledge gained from such research. This is particularly important to sustain current trends in blueberry production and to ensure its profitability.

Author Contributions: Conceptualization, S.U.N. and A.M.; Formal Analysis, J.W.D.; S.U.N. and A.M.; Resources, S.U.N. and A.M.; Data Curation, J.W.D., S.U.N. and A.M.; Writing-Original Draft Preparation, J.W.D., S.U.N. and A.M.; Writing-Review \& Editing, J.W.D., S.U.N. and A.M.; Visualization, S.U.N. and A.M.; Supervision, A.M.; Project Administration, S.U.N. and A.M.; Fund- 
ing Acquisition, S.U.N. and A.M. All authors have read and agreed to the published version of the manuscript.

Funding: Research in the laboratories of S.U.N. and A.M. are supported in part by the Southern Region Small Fruit Consortium.

Data Availability Statement: All data presented in the manuscript are either included within the manuscript or are derived from published literature.

Conflicts of Interest: The authors declare no conflict of interest. The funding agency had no role in the design, execution, interpretation, or writing of the study.

\section{References}

1. Jeyabalan, J.; Aqil, F.; Munagala, R.; Annamalai, L.; Vadhanam, M.V.; Gupta, R.C. Chemopreventive and therapeutic activity of dietary blueberry against estrogen-mediated breast cancer. J. Agric. Food Chem. 2014, 62, 3963-3971. [CrossRef] [PubMed]

2. Silva, S.; Costa, E.M.; Veiga, M.; Morais, R.M.; Calhau, C.; Pintado, M. Health promoting properties of blueberries: A review. Crit. Rev. Food Sci. Nutr. 2020, 60, 181-200. [CrossRef] [PubMed]

3. Davidson, K.T.; Zhu, Z.; Balabanov, D.; Zhao, L.; Wakefield, M.R.; Bai, Q.; Fang, Y. Beyond conventional medicine-a look at blueberry, a cancer-fighting superfruit. Pathol. Oncol. Res. 2018, 24, 733-738. [CrossRef]

4. Food and Agriculture Organization of the United Nations. 2019. Available online: http://www.fao.org/faostat/ (accessed on 15 December 2020).

5. Gupta, V.; Estrada, A.D.; Blakley, I.; Reid, R.; Patel, K.; Meyer, M.D.; Andersen, S.U.; Brown, A.F.; Lila, M.A.; Loraine, A.E. RNA-Seq analysis and annotation of a draft blueberry genome assembly identifies candidate genes involved in fruit ripening, biosynthesis of bioactive compounds, and stage-specific alternative splicing. GigaScience 2015, 4, 5. [CrossRef] [PubMed]

6. Colle, M.; Leisner, C.P.; Wai, C.M.; Ou, S.; Bird, K.A.; Wang, J.; Wisecaver, J.H.; Yocca, A.E.; Alger, E.I.; Tang, H. Haplotype-phased genome and evolution of phytonutrient pathways of tetraploid blueberry. GigaScience 2019, 8, giz012. [CrossRef] [PubMed]

7. Korcak, R.F. Nutrition of blueberry and other calcifuges. Hortic. Rev. 1988, 10, 183-227.

8. Retamales, J.; Hancock, J.F. Blueberries; CAB International: Boston, MA, USA, 2012.

9. Townsend, L. Influence of form of nitrogen and $\mathrm{pH}$ on growth and nutrient levels in the leaves and roots of the lowbush blueberry. Can. J. Sci. 1969, 49, 333-338. [CrossRef]

10. Rosen, C.J.; Allan, D.L.; Luby, J.J. Nitrogen form and solution $\mathrm{pH}$ influence growth and nutrition of two Vaccinium clones. J. Am. Soc. Hortic. Sci. 1990, 115, 83-89. [CrossRef]

11. Sugiyama, N.; Hanawa, S. Growth responses of rabbiteye blueberry plants to $\mathrm{N}$ forms at constant $\mathrm{pH}$ in solution culture. J. Jpn. Soc. Hortic. Sci. 1992, 61, 25-29. [CrossRef]

12. Hanson, E.J.; Retamales, J.B. Effect of nitrogen source and timing on highbush blueberry performance. HortScience 1992, 27, 1265-1267. [CrossRef]

13. Banados, M.P.; Strik, B.C.; Bryla, D.R.; Righetti, T.L.J.H. Response of highbush blueberry to nitrogen fertilizer during field establishment, I: Accumulation and allocation of fertilizer nitrogen and biomass. HortScience 2012, 47, 648-655. [CrossRef]

14. Bryla, D.R.; Strik, B.C.; Banados, M.P.; Righetti, T.L. Response of highbush blueberry to nitrogen fertilizer during field establishment-II. Plant nutrient requirements in relation to nitrogen fertilizer supply. HortScience 2012, 47, 917-926. [CrossRef]

15. Fang, Y.; Williamson, J.; Darnell, R.; Li, Y.; Liu, G. Optimizing Nitrogen Fertigation Rates for Young Southern Highbush Blueberry. Agronomy 2020, 10, 389. [CrossRef]

16. Masclaux-Daubresse, C.; Daniel-Vedele, F.; Dechorgnat, J.; Chardon, F.; Gaufichon, L.; Suzuki, A. Nitrogen uptake, assimilation and remobilization in plants: Challenges for sustainable and productive agriculture. Ann. Bot. 2010, 105, 1141-1157. [CrossRef]

17. Birkhold, K.T.; Darnell, R.L. Contribution of storage and currently assimilated nitrogen to vegetative and reproductive growth of rabbiteye blueberry. J. Am. Soc. Hortic. Sci. 1993, 118, 101-108. [CrossRef]

18. Stribley, D.; Read, D. The biology of mycorrhiza in the Ericaceae: VII. The relationship between mycorrhizal infection and the capacity to utilize simple and complex organic nitrogen sources. New Phytol. 1980, 86, 365-371. [CrossRef]

19. Näsholm, T.; Kielland, K.; Ganeteg, U. Uptake of organic nitrogen by plants. New Phytol. 2009, 182, 31-48. [CrossRef] [PubMed]

20. Näsholm, T.; Huss-Danell, K.; Högberg, P. Uptake of organic nitrogen in the field by four agriculturally important plant species. Ecology 2000, 81, 1155-1161. [CrossRef]

21. Tegeder, M.; Rentsch, D. Uptake and partitioning of amino acids and peptides. Mol. Plant 2010, 3, 997-1011. [CrossRef] [PubMed]

22. Yao, X.; Nie, J.; Bai, R.; Sui, X. Amino acid transporters in plants: Identification and function. Plants 2020, 9, 972. [CrossRef] [PubMed]

23. Lee, Y.H.; Foster, J.; Chen, J.; Voll, L.M.; Weber, A.P.; Tegeder, M. AAP1 transports uncharged amino acids into roots of Arabidopsis. Plant J. 2007, 50, 305-319. [CrossRef] [PubMed]

24. Svennerstam, H.; Ganeteg, U.; Näsholm, T. Root uptake of cationic amino acids by Arabidopsis depends on functional expression of amino acid permease 5. New Phytol. 2008, 180, 620-630. [CrossRef] [PubMed]

25. Chen, L.; Bush, D.R. LHT1, a lysine-and histidine-specific amino acid transporter in arabidopsis. Plant Physiol. 1997, 115, 1127-1134. [CrossRef] 
26. Hirner, A.; Ladwig, F.; Stransky, H.; Okumoto, S.; Keinath, M.; Harms, A.; Frommer, W.B.; Koch, W. Arabidopsis LHT1 is a high-affinity transporter for cellular amino acid uptake in both root epidermis and leaf mesophyll. Plant Cell 2006, 18, $1931-1946$. [CrossRef] [PubMed]

27. Perchlik, M.; Foster, J.; Tegeder, M. Different and overlapping functions of Arabidopsis LHT6 and AAP1 transporters in root amino acid uptake. J. Exp. Bot. 2014, 65, 519-5204. [CrossRef] [PubMed]

28. Grallath, S.; Weimar, T.; Meyer, A.; Gumy, C.; Suter-Grotemeyer, M.; Neuhaus, J.-M.; Rentsch, D. The AtProT family. Compatible solute transporters with similar substrate specificity but differential expression patterns. Plant Physiol. 2005, 137, 117-126. [CrossRef] [PubMed]

29. Lehmann, S.; Gumy, C.; Blatter, E.; Boeffel, S.; Fricke, W.; Rentsch, D. In planta function of compatible solute transporters of the AtProT family. J. Exp. Bot. 2011, 62, 787-796. [CrossRef] [PubMed]

30. Komarova, N.Y.; Thor, K.; Gubler, A.; Meier, S.; Dietrich, D.; Weichert, A.; Grotemeyer, M.S.; Tegeder, M.; Rentsch, D. AtPTR1 and AtPTR5 transport dipeptides in planta. Plant Physiol. 2008, 148, 856-869. [CrossRef] [PubMed]

31. Dietrich, D.; Hammes, U.; Thor, K.; Suter-Grotemeyer, M.; Flückiger, R.; Slusarenko, A.J.; Ward, J.M.; Rentsch, D. AtPTR1, a plasma membrane peptide transporter expressed during seed germination and in vascular tissue of Arabidopsis. Plant J. 2004, 40, 488-499. [CrossRef]

32. Paungfoo-Lonhienne, C.; Lonhienne, T.G.; Rentsch, D.; Robinson, N.; Christie, M.; Webb, R.I.; Gamage, H.K.; Carroll, B.J.; Schenk, P.M.; Schmidt, S. Plants can use protein as a nitrogen source without assistance from other organisms. Proc. Natl. Acad. Sci. USA 2008, 105, 4524-4529. [CrossRef] [PubMed]

33. Payá-Milans, M.; Nunez, G.H.; Olmstead, J.W.; Rinehart, T.A.; Staton, M. Regulation of gene expression in roots of the pHsensitive Vaccinium corymbosum and the $\mathrm{pH}$-tolerant Vaccinium arboreum in response to near neutral $\mathrm{pH}$ stress using RNA-Seq. BMC Genom. 2017, 18, 580. [CrossRef] [PubMed]

34. Read, D. The structure and function of the ericoid mycorrhizal root. Ann. Bot. 1996, 77, 365-374. [CrossRef]

35. Scagel, C.F. Inoculation with ericoid mycorrhizal fungi alters fertilizer use of highbush blueberry cultivars. HortScience 2005, 40, 786-794. [CrossRef]

36. Stribley, D.; Read, D. The biology of mycorrhiza in the Ericaceae IV. The effect of mycorrhizal infection on uptake of ${ }^{15} \mathrm{~N}$ from labelled soil by Vaccinium macrocarpon ait. New Phytol. 1974, 73, 1149-1155. [CrossRef]

37. Kosola, K.R.; Workmaster, B.A.A.; Spada, P.A. Inoculation of cranberry (Vaccinium macrocarpon) with the ericoid mycorrhizal fungus Rhizoscyphus ericae increases nitrate influx. New Phytol. 2007, 176, 184-196. [CrossRef] [PubMed]

38. Näsholm, T.; Ekblad, A.; Nordin, A.; Giesler, R.; Högberg, M.; Högberg, P. Boreal forest plants take up organic nitrogen. Nature 1998, 392, 914-916. [CrossRef]

39. Bajwa, R.; Read, D. The biology of mycorrhiza in the Ericaceae: IX. Peptides as nitrogen sources for the ericoid endophyte and for mycorrhizal and non-mycorrhizal plants. New Phytol. 1985, 101, 459-467. [CrossRef]

40. Scagel, C.F.; Yang, W.Q. Cultural variation and mycorrhizal status of blueberry plants in NW Oregon commercial production fields. Int. J. Fruit Sci. 2005, 5, 85-111. [CrossRef]

41. Sadowsky, J.J.; Hanson, E.J.; Schilder, A.M.C. Root colonization by ericoid mycorrhizae and dark septate endophytes in organic and conventional blueberry fields in Michigan. Int. J. Fruit Sci. 2012, 12, 169-187. [CrossRef]

42. Li, J.; Mavrodi, O.V.; Hou, J.; Blackmon, C.; Babiker, E.M.; Mavrodi, D.V. Comparative analysis of rhizosphere microbiomes of southern highbush blueberry (Vaccinium corymbosum L.), Darrow's blueberry (V. darrowii Camp), and rabbiteye blueberry ( $V$. virgatum Aiton). Front. Microbiol. 2020, 11, 370. [CrossRef]

43. Powell, C.L.; Bates, P.M. Ericoid mycorrhizas stimulate fruit yield of blueberry. HortScience 1981, 16, 655-656.

44. Haynes, R.; Swift, R. Growth and nutrient uptake by highbush blueberry plants in a peat medium as influenced by pH, applied micronutrients and mycorrhizal inoculation. Sci. Hortic. 1985, 27, 285-294. [CrossRef]

45. Boudsocq, S.; Lata, J.-C.; Mathieu, J.; Abbadie, L.; Barot, S. Modelling approach to analyse the effects of nitrification inhibition on primary production. Funct. Ecol. 2009, 23, 220-230. [CrossRef]

46. Britto, D.T.; Kronzucker, H.J. Ecological significance and complexity of N-source preference in plants. Ann. Bot. 2013, 112, 957-963. [CrossRef]

47. Haynes, R.; Goh, K.M. Ammonium and nitrate nutrition of plants. Biol. Rev. 1978, 53, 465-510. [CrossRef]

48. Cain, J.C. A comparison of ammonium and nitrate nitrogen for blueberries. Proc. Am. Soc. Hortic. Sci. 1952, 59, 161-166.

49. Herath, H.; Eaton, G. Some effects of water table, $\mathrm{pH}$, and nitrogen fertilization upon growth and nutrient-element content of high bush blueberry plants. Proc. Am. Soc. Hortic. Sci. 1968, 92, 274-283.

50. Townsend, L. Effect of nitrate and ammonium nitrogen on the growth of the lowbush blueberry. Can. J. Plant Sci. 1966, 46, 209-210. [CrossRef]

51. Townsend, L. Effect of ammonium nitrogen and nitrate nitrogen, separately and in combination, on the growth of the highbush blueberry. Can. J. Plant Sci. 1967, 47, 555-562. [CrossRef]

52. Osorio, R.; Cáceres, C.; Covarrubias, J.I. Vegetative and physiological responses of "Emerald" blueberry to Ammoniacal sources with a nitrification inhibitor. J. Soil Sci. Plant Nutr. 2019, 20, 507-515. [CrossRef]

53. Poonnachit, U.; Darnell, R. Effect of ammonium and nitrate on ferric chelate reductase and nitrate reductase in Vaccinium species. Ann. Bot. 2004, 93, 399-405. [CrossRef] [PubMed] 
54. Merhaut, D.J.; Darnell, R.L. Ammonium and nitrate accumulation in containerized southern highbush blueberry plants. HortScience 1995, 30, 1378-1381. [CrossRef]

55. Oertli, J. Effect of form of nitrogen and pH on growth of blueberry plants. Agron. J. 1963, 55, 305-307. [CrossRef]

56. Alt, D.S.; Doyle, J.W.; Malladi, A. Nitrogen-source preference in blueberry (Vaccinium sp.): Enhanced shoot nitrogen assimilation in response to direct supply of nitrate. J. Plant Physiol. 2017, 216, 79-87. [CrossRef] [PubMed]

57. Takamizo, T.; Sugiyama, N. Growth responses to N forms in rabbiteye and highbush blueberries. J. Jpn. Soc. Hortic. Sci. 1991, 60, 41-45. [CrossRef]

58. Claussen, W.; Lenz, F. Effect of ammonium or nitrate nutrition on net photosynthesis, growth, and activity of the enzymes nitrate reductase and glutamine synthetase in blueberry, raspberry and strawberry. Plant Soil 1999, 208, 95-102. [CrossRef]

59. Hammett, L.; Ballinger, W. A nutrient solution-sand culture system for studying the influence of $\mathrm{N}$ form on highbush blueberries. HortScience 1972, 7, 498-500.

60. Hayatsu, M.; Tago, K.; Saito, M. Various players in the nitrogen cycle: Diversity and functions of the microorganisms involved in nitrification and denitrification. Soil Sci. Plant Nutr. 2008, 54, 33-45. [CrossRef]

61. Coskun, D.; Britto, D.T.; Shi, W.; Kronzucker, H.J. Nitrogen transformations in modern agriculture and the role of biological nitrification inhibition. Nat. Plants 2017, 3, 17074. [CrossRef]

62. Hu, H.-W.; Xu, Z.-H.; He, J.-Z. Ammonia-oxidizing archaea play a predominant role in acid soil nitrification. Adv. Agron. 2014, 125, 261-302.

63. Könneke, M.; Bernhard, A.E.; José, R.; Walker, C.B.; Waterbury, J.B.; Stahl, D.A. Isolation of an autotrophic ammonia-oxidizing marine archaeon. Nature 2005, 437, 543-546. [CrossRef]

64. Leininger, S.; Urich, T.; Schloter, M.; Schwark, L.; Qi, J.; Nicol, G.W.; Prosser, J.I.; Schuster, S.; Schleper, C. Archaea predominate among ammonia-oxidizing prokaryotes in soils. Nature 2006, 442, 806-809. [CrossRef] [PubMed]

65. Lehtovirta-Morley, L.E.; Stoecker, K.; Vilcinskas, A.; Prosser, J.I.; Nicol, G.W. Cultivation of an obligate acidophilic ammonia oxidizer from a nitrifying acid soil. Proc. Natl. Acad. Sci. USA 2011, 108, 15892-15897. [CrossRef] [PubMed]

66. Throop, P.A.; Hanson, E.J. Nitrification and utilization of fertilizer nitrogen by highbush blueberry. J. Plant Nutr. 1998, 21, 1731-1742. [CrossRef]

67. Subbarao, G.V.; Ito, O.; Sahrawat, K.L.; Berry, W.L.; Nakahara, K.; Ishikawa, T.; Watanabe, T.; Suenaga, K.; Rondon, M.; Rao, I.M. Scope and Strategies for Regulation of Nitrification in Agricultural Systems-Challenges and Opportunities. Crit. Rev. Plant Sci. 2006, 25, 303-335. [CrossRef]

68. Martínez-Alcántara, B.; Quiñones, A.; Polo, C.; Primo-Millo, E.; Legaz, F. Use of nitrification inhibitor DMPP to improve nitrogen uptake efficiency in citrus trees. J. Agric. Sci. 2013, 5, 1-18. [CrossRef]

69. Covarrubias, J.I.; Pisi, A.; Rombolà, A.D. Evaluation of sustainable management techniques for preventing iron chlorosis in the grapevine. Aust. J. Grape Wine Res. 2014, 20, 149-159. [CrossRef]

70. Martínez, F.; Palencia, P.; Weiland, C.; Alonso, D.; Oliveira, J. Influence of nitrification inhibitor DMPP on yield, fruit quality and SPAD values of strawberry plants. Sci. Hortic. 2015, 185, 233-239. [CrossRef]

71. Sun, L.; Lu, Y.; Yu, F.; Kronzucker, H.J.; Shi, W. Biological nitrification inhibition by rice root exudates and its relationship with nitrogen-use efficiency. New Phytol. 2016, 212, 646-656. [CrossRef]

72. Subbarao, G.; Rondon, M.; Ito, O.; Ishikawa, T.; Rao, I.M.; Nakahara, K.; Lascano, C.; Berry, W. Biological nitrification inhibition (BNI)-Is it a widespread phenomenon? Plant Soil 2007, 294, 5-18. [CrossRef]

73. Tanaka, J.P.; Nardi, P.; Wissuwa, M. Nitrification inhibition activity, a novel trait in root exudates of rice. AoB Plants 2010, 2010, plq014.

74. Siddiqi, M.Y.; Glass, A.D.; Ruth, T.J.; Rufty, T.W. Studies of the uptake of nitrate in barley: I. Kinetics of ${ }^{13} \mathrm{NO}_{3}{ }^{-}$influx. Plant Physiol. 1990, 93, 1426-1432. [CrossRef] [PubMed]

75. Kronzucker, H.J.; Siddiqi, M.Y.; Glass, A.D. Kinetics of $\mathrm{NO}_{3}{ }^{-}$influx in spruce. Plant Physiol. 1995, 109, 319-326. [CrossRef]

76. Kronzucker, H.J.; Siddiqi, M.Y.; Glass, A.D. Kinetics of $\mathrm{NH}_{4}{ }^{+}$influx in spruce. Plant Physiol. 1996, 110, 773-779. [CrossRef]

77. Wang, M.Y.; Siddiqi, M.Y.; Ruth, T.J.; Glass, A.D. Ammonium uptake by rice roots (I. Fluxes and subcellular distribution of ${ }^{13} \mathrm{NH}_{4}{ }^{+}$). Plant Physiol. 1993, 103, 1249-1258. [CrossRef] [PubMed]

78. Aslam, M.; Travis, R.L.; Huffaker, R.C. Comparative kinetics and reciprocal inhibition of nitrate and nitrite uptake in roots of uninduced and induced barley (Hordeum vulgare L.) seedlings. Plant Physiol. 1992, 99, 1124-1133. [CrossRef] [PubMed]

79. Crawford, N.M.; Glass, A.D. Molecular and physiological aspects of nitrate uptake in plants. Trends Plant Sci. 1998, 3, 389-395. [CrossRef]

80. Tischner, R. Nitrate uptake and reduction in plants. J. Crop Improv. 2006, 15, 53-95. [CrossRef]

81. Miller, A.J.; Fan, X.; Orsel, M.; Smith, S.J.; Wells, D.M. Nitrate transport and signalling. J. Exp. Bot. 2007, 58, 2297-2306. [CrossRef]

82. Sugiyama, N.; Ishigaki, K. Uptake of nitrate-nitrogen by blueberry plants. J. Plant Nutr. 1994, 17, 1975-1982. [CrossRef]

83. Wang, M.Y.; Siddiqi, M.Y.; Ruth, T.J.; Glass, A.D. Ammonium uptake by rice roots (II. Kinetics of ${ }^{13} \mathrm{NH}_{4}{ }^{+}$influx across the plasmalemma). Plant Physiol. 1993, 103, 1259-1267. [CrossRef] [PubMed]

84. Youngdahl, L.; Pacheco, R.; Street, J.; Vlek, P. The kinetics of ammonium and nitrate uptake by young rice plants. Plant Soil 1982, 69, 225-232. [CrossRef]

85. Sugiyama, N.; Hirooka, M. Uptake of ammonium-nitrogen by blueberry plants. J. Plant Nutr. 1993, 16, 1975-1981. [CrossRef] 
86. Kronzucker, H.J.; Siddiqi, M.Y.; Glass, A.D. Conifer root discrimination against soil nitrate and the ecology of forest succession. Nature 1997, 385, 59-61. [CrossRef]

87. Wang, Y.-Y.; Hsu, P.-K.; Tsay, Y.-F. Uptake, allocation and signaling of nitrate. Trends Plant Sci. 2012, 17, 458-467. [CrossRef] [PubMed]

88. Wang, Y.-Y.; Cheng, Y.-H.; Chen, K.-E.; Tsay, Y.-F. Nitrate transport, signaling, and use efficiency. Annu. Rev. Plant Biol. 2018, 69, 85-122. [CrossRef] [PubMed]

89. Krapp, A.; David, L.C.; Chardin, C.; Girin, T.; Marmagne, A.; Leprince, A.-S.; Chaillou, S.; Ferrario-Méry, S.; Meyer, C.; Daniel-Vedele, F. Nitrate transport and signalling in Arabidopsis. J. Exp. Bot. 2014, 65, 789-798. [CrossRef] [PubMed]

90. Li, W.; Wang, Y.; Okamoto, M.; Crawford, N.M.; Siddiqi, M.Y.; Glass, A.D. Dissection of the AtNRT2. 1: AtNRT2. 2 inducible high-affinity nitrate transporter gene cluster. Plant Physiol. 2007, 143, 425-433. [CrossRef]

91. Liu, K.H.; Tsay, Y.F. Switching between the two action modes of the dual-affinity nitrate transporter CHL1 by phosphorylation. EMBO J. 2003, 22, 1005-1013. [CrossRef]

92. Ho, C.-H.; Lin, S.-H.; Hu, H.-C.; Tsay, Y.-F. CHL1 functions as a nitrate sensor in plants. Cell 2009, 138, 1184-1194. [CrossRef]

93. Huang, N.-C.; Liu, K.-H.; Lo, H.-J.; Tsay, Y.-F. Cloning and functional characterization of an Arabidopsis nitrate transporter gene that encodes a constitutive component of low-affinity uptake. Plant Cell 1999, 11, 1381-1392. [CrossRef]

94. Ludewig, U.; Neuhäuser, B.; Dynowski, M. Molecular mechanisms of ammonium transport and accumulation in plants. FEBS Lett. 2007, 581, 2301-2308. [CrossRef] [PubMed]

95. Kiba, T.; Krapp, A. Plant nitrogen acquisition under low availability: Regulation of uptake and root architecture. Plant Cell Physiol. 2014, 57, 707-714. [CrossRef] [PubMed]

96. Tegeder, M.; Masclaux-Daubresse, C. Source and sink mechanisms of nitrogen transport and use. New Phytol. 2018, 217, 35-53. [CrossRef] [PubMed]

97. Loqué, D.; Yuan, L.; Kojima, S.; Gojon, A.; Wirth, J.; Gazzarrini, S.; Ishiyama, K.; Takahashi, H.; Von Wirén, N. Additive contribution of AMT1; 1 and AMT1; 3 to high-affinity ammonium uptake across the plasma membrane of nitrogen-deficient Arabidopsis roots. Plant J. 2006, 48, 522-534. [CrossRef] [PubMed]

98. Segonzac, C.; Boyer, J.-C.; Ipotesi, E.; Szponarski, W.; Tillard, P.; Touraine, B.; Sommerer, N.; Rossignol, M.; Gibrat, R. Nitrate efflux at the root plasma membrane: Identification of an Arabidopsis excretion transporter. Plant Cell 2007, 19, 3760-3777. [CrossRef] [PubMed]

99. Britto, D.T.; Kronzucker, H.J. Futile cycling at the plasma membrane: A hallmark of low-affinity nutrient transport. Trends Plant Sci. 2006, 11, 529-534. [CrossRef] [PubMed]

100. Lin, S.-H.; Kuo, H.-F.; Canivenc, G.; Lin, C.-S.; Lepetit, M.; Hsu, P.-K.; Tillard, P.; Lin, H.-L.; Wang, Y.-Y.; Tsai, C.-B. Mutation of the Arabidopsis NRT1. 5 nitrate transporter causes defective root-to-shoot nitrate transport. Plant Cell 2008, 20, 2514-2528. [CrossRef] [PubMed]

101. Xu, G.; Fan, X.; Miller, A.J. Plant nitrogen assimilation and use efficiency. Annu. Rev. Plant Biol. 2012, 63, 153-182. [CrossRef]

102. Britto, D.T.; Siddiqi, M.Y.; Glass, A.D.; Kronzucker, H.J. Futile transmembrane $\mathrm{NH}_{4}{ }^{+}$cycling: A cellular hypothesis to explain ammonium toxicity in plants. Proc. Natl. Acad. Sci. USA 2001, 98, 4255-4258. [CrossRef]

103. Britto, D.T.; Kronzucker, H.J. $\mathrm{NH}_{4}{ }^{+}$toxicity in higher plants: A critical review. J. Plant Physiol. 2002, 159, 567-584. [CrossRef]

104. Howitt, S.M.; Udvardi, M.K. Structure, function and regulation of ammonium transporters in plants. Biochim. Biophys. Acta (BBA) Biomembr. 2000, 1465, 152-170. [CrossRef]

105. Tobin, A.K.; Yamaya, T. Cellular compartmentation of ammonium assimilation in rice and barley. J. Exp. Bot. 2001, 52, 591-604. [CrossRef]

106. Schjoerring, J.K.; Husted, S.; Mäck, G.; Mattsson, M. The regulation of ammonium translocation in plants. J. Exp. Bot. 2002, 53, 883-890. [CrossRef] [PubMed]

107. Darnell, R.L.; Hiss, S.A. Uptake and assimilation of nitrate and iron in two Vaccinium species as affected by external nitrate concentration. J. Am. Soc. Hortic. Sci. 2006, 131, 5-10. [CrossRef]

108. Cruz, C.; Soares, M.; Martins-Loucao, M.; Lips, S. Nitrate reduction in seedlings of carob (Ceratonia siliqua L.). New Phytol. 1991, 119, 413-419. [CrossRef]

109. Cruz, C.; Lips, S.H.; Martins-Loução, M.A. Nitrogen assimilation and transport in carob plants. Physiol. Plant. 1993, 89, 524-531. [CrossRef]

110. Min, X.; Siddiqi, M.; Guy, R.; Glass, A.; Kronzucker, H. Induction of nitrate uptake and nitrate reductase activity in trembling aspen and lodgepole pine. Plant Cell Environ. 1998, 21, 1039-1046. [CrossRef]

111. Min, X.; Siddiqi, Y.M.; Guy, R.; Glass, A.; Kronzucker, H. A comparative study of fluxes and compartmentation of nitrate and ammonium in early-successional tree species. Plant Cell Environ. 1999, 22, 821-830. [CrossRef]

112. Lea, P.; Miflin, B. Alternative route for nitrogen assimilation in higher plants. Nature 1974, 251, 614-616. [CrossRef]

113. Funayama, K.; Kojima, S.; Tabuchi-Kobayashi, M.; Sawa, Y.; Nakayama, Y.; Hayakawa, T.; Yamaya, T. Cytosolic glutamine synthetase1; 2 is responsible for the primary assimilation of ammonium in rice roots. Plant Cell Physiol. 2013, 54, 934-943. [CrossRef]

114. Smirnoff, N.; Stewart, G. Nitrate assimilation and translocation by higher plants: Comparative physiology and ecological consequences. Physiol. Plant. 1985, 64, 133-140. [CrossRef]

115. Pate, J. Transport and partitioning of nitrogenous solutes. Annu. Rev. Plant Physiol. 1980, 31, 313-340. [CrossRef] 
116. Smirnoff, N.; Todd, P.; Stewart, G. The occurrence of nitrate reduction in the leaves of woody plants. Ann. Bot. 1984, 54, 363-374. [CrossRef]

117. Dirr, M.; Barker, A.; Maynard, D. Nitrate reductase activity in the leaves of the highbush blueberry and other plants. J. Am. Soc. Hortic. Sci. 1972, 97, 329-331.

118. Aslam, M.; Rosichan, J.L.; Huffaker, R.C. Comparative induction of nitrate reductase by nitrate and nitrite in barley leaves. Plant Physiol. 1987, 83, 579-584. [CrossRef] [PubMed]

119. Aslam, M.; Huffaker, R.C. Role of nitrate and nitrite in the induction of nitrite reductase in leaves of barley seedlings. Plant Physiol. 1989, 91, 1152-1156. [CrossRef]

120. Crawford, N.M.; Arst Jr, H.N. The molecular genetics of nitrate assimilation in fungi and plants. Annu. Rev. Genet. 1993, 27, 115-146. [CrossRef]

121. Darnell, R.L.; Cruz-Huerta, N. Uptake and assimilation of nitrate and iron in cultivated and wild Vaccinium species. Int. J. Fruit Sci. 2011, 11, 136-150. [CrossRef]

122. Titus, J.S.; Kang, S.-M. Nitrogen metabolism, translocation, and recycling in apple trees. Hortic. Rev. 1982, 4, $204-246$.

123. Tromp, J. Nutrient reserves in roots of fruit trees, in particular carbohydrates and nitrogen. Plant Soil 1983, 71, 401-413. [CrossRef]

124. Millard, P.; Grelet, G.-A. Nitrogen storage and remobilization by trees: Ecophysiological relevance in a changing world. Tree Physiol. 2010, 30, 1083-1095. [CrossRef]

125. Carranca, C.; Brunetto, G.; Tagliavini, M. Nitrogen nutrition of fruit trees to reconcile productivity and environmental concerns. Plants 2018, 7, 4. [CrossRef]

126. Cheng, L.; Fuchigami, L.H. Growth of young apple trees in relation to reserve nitrogen and carbohydrates. Tree Physiol. 2002, 22, 1297-1303. [CrossRef] [PubMed]

127. Cheng, L.; Ma, F.; Ranwala, D. Nitrogen storage and its interaction with carbohydrates of young apple trees in response to nitrogen supply. Tree Physiol. 2004, 24, 91-98. [CrossRef] [PubMed]

128. Grelet, G.A.; Alexander, I.J.; Proe, M.F.; Frossard, J.S.; Millard, P. Leaf habit influences nitrogen remobilization in Vaccinium species. J. Exp. Bot. 2001, 52, 993-1002. [CrossRef] [PubMed]

129. Tagliavini, M.; Millard, P.; Quartieri, M.; Marangoni, B. Timing of nitrogen uptake affects winter storage and spring remobilisation of nitrogen in nectarine (Prunus persica var. nectarina) trees. Plant Soil 1999, 211, 149-153. [CrossRef]

130. Niederholzer, F.; DeJong, T.; Saenz, J.-L.; Muraoka, T.; Weinbaum, S. Effectiveness of fall versus spring soil fertilization of field-grown peach trees. J. Am. Soc. Hortic. Sci. 2001, 125, 644-648. [CrossRef]

131. Rosecrance, R.C.; Weinbaum, S.A.; Brown, P.H. Alternate bearing affects nitrogen, phosphorus, potassium and starch storage pools in mature pistachio trees. Ann. Bot. 1998, 82, 463-470. [CrossRef]

132. Marschner, H. Mineral Nutrition of Higher Plants, 2nd ed.; Academic Press: London, UK, 1995.

133. White, P.J.; Broadley, M.R. Calcium in plants. Ann. Bot. 2003, 92, 487-511. [CrossRef]

134. Bangerth, F. Calcium-related physiological disorders of plants. Annu. Rev. Phytopathol. 1979, 17, 97-122. [CrossRef]

135. Hart, J.M.; Strik, B.; White, L.; Yang, W. Nutrient Management for Blueberries in Oregon; Oregon State University Extension Service Publication: Corvallis, OR, USA, 2006.

136. Dayod, M.; Tyerman, S.D.; Leigh, R.A.; Gilliham, M. Calcium storage in plants and the implications for calcium biofortification. Protoplasma 2010, 247, 215-231. [CrossRef]

137. Raleigh, S.; Chucka, J. Effect of nutrient ratio and concentration on growth and composition of tomato plants and on the occurence of blossom-end rot of the fruit. Plant Physiol. 1944, 19, 671-678. [CrossRef] [PubMed]

138. Ho, L.; Adams, P.; Li, X.; Shen, H.; Andrews, J.; Xu, Z. Responses of Ca-efficient and Ca-inefficient tomato cultivars to salinity in plant growth, calcium accumulation and blossom-end rot. J. Hortic. Sci. 1995, 70, 909-918. [CrossRef]

139. Taylor, M.D.; Locascio, S.J. Blossom-end rot: A calcium deficiency. J. Plant Nutr. 2004, 27, 123-139. [CrossRef]

140. del Amor, F.M.; Rubio, J.S. Effects of antitranspirant spray and potassium: Calcium: Magnesium ratio on photosynthesis, nutrient and water uptake, growth, and yield of sweet pepper. J. Plant Nutr. 2009, 32, 97-111. [CrossRef]

141. Briggs, G.; Robertson, R. Apparent free space. Annu. Rev. Plant Physiol. 1957, 8, 11-30. [CrossRef]

142. Sattelmacher, B. The apoplast and its significance for plant mineral nutrition. New Phytol. 2001, 149, 167-192. [CrossRef]

143. Gilliham, M.; Dayod, M.; Hocking, B.J.; Xu, B.; Conn, S.J.; Kaiser, B.N.; Leigh, R.A.; Tyerman, S.D. Calcium delivery and storage in plant leaves: Exploring the link with water flow. J. Exp. Bot. 2011, 62, 2233-2250. [CrossRef] [PubMed]

144. Hocking, B.; Tyerman, S.D.; Burton, R.A.; Gilliham, M. Fruit calcium: Transport and physiology. Front. Plant Sci. 2016, 7, 569. [CrossRef] [PubMed]

145. McAinsh, M.R.; Pittman, J.K. Shaping the calcium signature. New Phytol. 2009, 181, 275-294. [CrossRef]

146. White, P.J. The pathways of calcium movement to the xylem. J. Exp. Bot. 2001, 52, 891-899. [CrossRef]

147. Karley, A.J.; White, P.J. Moving cationic minerals to edible tissues: Potassium, magnesium, calcium. Curr. Opin. Plant Biol. 2009, 12, 291-298. [CrossRef] [PubMed]

148. Kumar, A.; Singh, U.M.; Manohar, M.; Gaur, V.S. Calcium transport from source to sink: Understanding the mechanism (s) of acquisition, translocation, and accumulation for crop biofortification. Acta Physiol. Plant. 2015, 37, 1722. [CrossRef]

149. Demidchik, V.; Shabala, S.; Isayenkov, S.; Cuin, T.A.; Pottosin, I. Calcium transport across plant membranes: Mechanisms and functions. New Phytol. 2018, 220, 49-69. [CrossRef] [PubMed]

150. Conn, S.; Gilliham, M. Comparative physiology of elemental distributions in plants. Ann. Bot. 2010, 105, 1081-1102. [CrossRef] 
151. Thor, K. Calcium-Nutrient and messenger. Front. Plant Sci. 2019, 10, 440. [CrossRef]

152. Baxter, I.; Hosmani, P.S.; Rus, A.; Lahner, B.; Borevitz, J.O.; Muthukumar, B.; Mickelbart, M.V.; Schreiber, L.; Franke, R.B.; Salt, D.E. Root suberin forms an extracellular barrier that affects water relations and mineral nutrition in Arabidopsis. PLoS Genet. 2009, 5, e1000492. [CrossRef] [PubMed]

153. Cholewa, E.; Peterson, C.A. Evidence for symplastic involvement in the radial movement of calcium in onion roots. Plant Physiol. 2004, 134, 1793-1802. [CrossRef] [PubMed]

154. Höfer, R.; Briesen, I.; Beck, M.; Pinot, F.; Schreiber, L.; Franke, R. The Arabidopsis cytochrome P450 CYP86A1 encodes a fatty acid $\omega$-hydroxylase involved in suberin monomer biosynthesis. J. Exp. Bot. 2008, 59, 2347-2360. [CrossRef] [PubMed]

155. Molina, I.; Li-Beisson, Y.; Beisson, F.; Ohlrogge, J.B.; Pollard, M. Identification of an Arabidopsis feruloyl-coenzyme A transferase required for suberin synthesis. Plant Physiol. 2009, 151, 1317-1328. [CrossRef]

156. Ho, L.C. Environmental effects on the diurnal accumulation of ${ }^{45}$ Ca by young fruit and leaves of tomato plants. Ann. Bot. 1989, 63, 281-288. [CrossRef]

157. Adams, P.; Holder, R. Effects of humidity, Ca and salinity on the accumulation of dry matter and Ca by the leaves and fruit of tomato (Lycopersicon esculentum). J. Hortic. Sci. 1992, 67, 137-142. [CrossRef]

158. Frantz, J.M.; Ritchie, G.; Cometti, N.N.; Robinson, J.; Bugbee, B. Exploring the limits of crop productivity: Beyond the limits of tipburn in lettuce. J. Am. Soc. Hortic. Sci. 2004, 129, 331-338. [CrossRef] [PubMed]

159. Guichard, S.; Gary, C.; Leonardi, C.; Bertin, N. Analysis of growth and water relations of tomato fruits in relation to air vapor pressure deficit and plant fruit load. J. Plant Growth Regul. 2005, 24, 201-213. [CrossRef]

160. Schon, M.K. Effects of foliar antitranspirant or calcium nitrate applications on yield and blossom-end rot occurrence in greenhousegrown peppers. J. Plant Nutr. 1993, 16, 1137-1149. [CrossRef]

161. De Freitas, S.T.; McElrone, A.J.; Shackel, K.A.; Mitcham, E.J. Calcium partitioning and allocation and blossom-end rot development in tomato plants in response to whole-plant and fruit-specific abscisic acid treatments. J. Exp. Bot. 2014, 65, 235-247. [CrossRef]

162. Saure, M.C. Calcium translocation to fleshy fruit: Its mechanism and endogenous control. Sci. Hortic. 2005, 105, 65-89. [CrossRef]

163. Guttridge, C.; Bradfield, E.; Holder, R. Dependence of calcium transport into strawberry leaves on positive pressure in the xylem. Ann. Bot. 1981, 48, 473-480. [CrossRef]

164. Montanaro, G.; Dichio, B.; Xiloyannis, C. Significance of fruit transpiration on calcium nutrition in developing apricot fruit. J. Plant Nutr. Soil Sci. 2010, 173, 618-622. [CrossRef]

165. Montanaro, G.; Dichio, B.; Lang, A.; Mininni, A.N.; Xiloyannis, C. Fruit calcium accumulation coupled and uncoupled from its transpiration in kiwifruit. J. Plant Physiol. 2015, 181, 67-74. [CrossRef] [PubMed]

166. Banuelos, G.S.; Bangerth, F.; Marschner, H. Relationship between polar basipetal auxin transport and acropetal Ca ${ }^{2+}$ transport into tomato fruits. Physiol. Plant. 1987, 71, 321-327. [CrossRef]

167. Ho, L.C.; White, P.J. A cellular hypothesis for the induction of blossom-end rot in tomato fruit. Ann. Bot. 2005, 95, 571-581. [CrossRef]

168. De Freitas, S.T.; Mitcham, E.I. Factors involved in fruit calcium deficiency disorders. Hortic. Rev. 2012, 40, $107-146$.

169. Marcelis, L.; Ho, L. Blossom-end rot in relation to growth rate and calcium content in fruits of sweet pepper (Capsicum annuum L.). J. Exp. Bot. 1999, 50, 357-363. [CrossRef]

170. Heuvelink, E.; Körner, O. Parthenocarpic fruit growth reduces yield fluctuation and blossom-end rot in sweet pepper. Ann. Bot. 2001, 88, 69-74. [CrossRef]

171. Perring, M. The effects of environment and cultural practices on calcium concentration in the apple fruit. Commun. Soil Sci. Plant Anal. 1979, 10, 279-293. [CrossRef]

172. Tromp, J. The intake curve for calcium into apple fruits under various environmental conditions. Commun. Soil Sci. Plant Anal. 1979, 10, 325-335. [CrossRef]

173. Xiloyannis, C.; Celano, G.; Montanaro, G.; Dichio, B.; Sebastiani, L.; Minnocci, A. Water relations, calcium and potassium, concentration in fruits and leaves during annual growth in mature kiwifruit plants. Acta Hortic. 2001, 564, 129-134. [CrossRef]

174. Bernadac, A.; Jean-Baptiste, I.; Bertoni, G.; Morard, P. Change in calcium contents during melon (Cucumis melo L.) fruit development. Sci. Hortic. 1996, 66, 181-189.

175. Stückrath, R.; Quevedo, R.; de la Fuente, L.; Hernández, A.; Sepúlveda, V. Effect of foliar application of calcium on the quality of blueberry fruits. J. Plant Nutr. 2008, 31, 1299-1312. [CrossRef]

176. Yang, F.-H.; DeVetter, L.W.; Strik, B.C.; Bryla, D.R. Stomatal functioning and its influence on fruit calcium accumulation in northern highbush blueberry. HortScience 2020, 55, 96-102. [CrossRef]

177. Mayorga-Gómez, A.; Nambeesan, S.U.; Coolong, T.; Díaz-Pérez, J.C. Temporal relationship between calcium and fruit growth and development in bell pepper (Capsicum annuum L.). HortScience 2020, 55, 906-913. [CrossRef]

178. Song, W.; Yi, J.; Kurniadinata, O.F.; Wang, H.; Huang, X. Linking fruit Ca uptake capacity to fruit growth and pedicel anatomy, a cross-species study. Front. Plant Sci. 2018, 9, 575. [CrossRef] [PubMed]

179. Ho, L.; Belda, R.; Brown, M.; Andrews, J.; Adams, P. Uptake and transport of calcium and the possible causes of blossom-end rot in tomato. J. Exp. Bot. 1993, 44, 509-518. [CrossRef]

180. Dražeta, L.; Lang, A.; Hall, A.J.; Volz, R.K.; Jameson, P.E. Causes and effects of changes in xylem functionality in apple fruit. Ann. Bot. 2004, 93, 275-282. [CrossRef] [PubMed] 
181. Dichio, B.; Remorini, D.; Lang, S. Developmental changes in xylem functionality in kiwifruit fruit: Implications for fruit calcium accumulation. Acta Hortic. 2003, 610, 191-195. [CrossRef]

182. Montanaro, G.; Dichio, B.; Lang, A.; Mininni, A.N.; Nuzzo, V.; Clearwater, M.J.; Xiloyannis, C. Internal versus external control of calcium nutrition in kiwifruit. J. Plant Nutr. Soil Sci. 2014, 177, 819-830. [CrossRef]

183. Angeletti, P.; Castagnasso, H.; Miceli, E.; Terminiello, L.; Concellón, A.; Chaves, A.; Vicente, A.R. Effect of preharvest calcium applications on postharvest quality, softening and cell wall degradation of two blueberry (Vaccinium corymbosum) varieties. Postharvest Biol. Technol. 2010, 58, 98-103. [CrossRef]

184. Hanson, E.J.; Berkheimer, S.F. Effect of soil calcium applications on blueberry yield and quality. Small Fruits Rev. 2004, 3, 133-139. [CrossRef]

185. Hanson, E.J. Preharvest calcium sprays do not improve highbush blueberry (Vaccinium corymbosum L.) quality. HortScience 1995, 30, 977-978. [CrossRef]

186. Vance, A.J.; Jones, P.; Strik, B.C. Foliar calcium applications do not improve quality or shelf life of strawberry, raspberry, blackberry, or blueberry fruit. HortScience 2017, 52, 382-387. [CrossRef]

187. Manzi, M.; Lado, J. Foliar applications of calcium do not impact on fruit and leaf nutrient concentration or quality of 'O'Neal'blueberry. J. Hortic. Sci. Biotechnol. 2019, 94, 676-684. [CrossRef]

188. Smith, E.D. The effect of foliar calcium treatments on fruit weight and firmness of rabbiteye blueberry (Vaccinium virgatum Aiton). J. Am. Pomol. Soc. 2016, 70, 74-81.

189. Arrington, M.; DeVetter, L.W. Foliar applications of calcium and boron do not increase fruit set or yield in northern highbush blueberry (Vaccinium corymbosum). HortScience 2017, 52, 1259-1264. [CrossRef]

190. Blodgett, A.; Caldwell, R.; McManus, P. Effects of calcium salts on the cranberry fruit rot disease complex. Plant Dis. 2002, 86, 747-752. [CrossRef] [PubMed]

191. Yang, F.-H.; Bryla, D.R.; Strik, B.C. Critical temperatures and heating times for fruit damage in northern highbush blueberry. HortScience 2019, 54, 2231-2239. [CrossRef]

192. Lobos, T.; Retamales, J.; Escobar, A.L.; Hanson, E. Timing of foliar calcium sprays improves fruit firmness and antioxidants in "Liberty" blueberries. J. Soil Sci. Plant Nutr. 2020. [CrossRef]

193. Gerbrandt, E.M.; Mouritzen, C.; Sweeney, M. Foliar calcium corrects a deficiency causing green fruit drop in 'Draper' highbush blueberry (Vaccinium corymbosum L.). Agriculture 2019, 9, 63. [CrossRef]

194. Hanson, E.J.; Beggs, J.L.; Beaudry, R.M. Applying calcium chloride postharvest to improve highbush blueberry firmness. HortScience 1993, 28, 1033-1034. [CrossRef]

195. Tang, R.-J.; Luan, S. Regulation of calcium and magnesium homeostasis in plants: From transporters to signaling network. Curr. Opin. Plant Biol. 2017, 39, 97-105. [CrossRef] [PubMed]

196. Maillard, A.; Diquélou, S.; Billard, V.; Laîné, P.; Garnica, M.; Prudent, M.; Garcia-Mina, J.-M.; Yvin, J.-C.; Ourry, A. Leaf mineral nutrient remobilization during leaf senescence and modulation by nutrient deficiency. Front. Plant Sci. 2015, 6, 317. [CrossRef] [PubMed]

197. Malone, M.; White, P.; Morales, M.A. Mobilization of calcium in glasshouse tomato plants by localized scorching. J. Exp. Bot. 2002, 53, 83-88. [CrossRef] [PubMed]

198. Paiva, E.A.S. Are calcium oxalate crystals a dynamic calcium store in plants? New Phytol. 2019, 223, 1707-1711. [CrossRef] [PubMed]

199. Franceschi, V.R.; Nakata, P.A. Calcium oxalate in plants: Formation and function. Annu. Rev. Plant Biol. 2005, 56, 41-71. [CrossRef]

200. Gallaher, R.N.; Jones, J.B.J. Total, extractable and oxalate calcium and other elements in normal and mouse ear pecan tree tissues. J. Am. Soc. Hortic. Sci. 1976, 101, 692-696.

201. Gallaher, R.N.; Perkins, H.F.; Jones, J.B.J. Calcium concentration and distribution in healthy and decline peach tree tissues. HortScience 1975, 10, 134-137.

202. Storey, R.; Jones, R.G.W.; Schachtman, D.P.; Treeby, M.T. Calcium-accumulating cells in the meristematic region of grapevine root apices. Funct. Plant Biol. 2003, 30, 719-727. [CrossRef] [PubMed]

203. Volk, G.; Lynch-Holm, V.; Kostman, T.; Goss, L.; Franceschi, V. The role of druse and raphide calcium oxalate crystals in tissue calcium regulation in Pistia stratiotes leaves. Plant Biol. 2002, 4, 34-45. [CrossRef] 